\title{
CUP-MARKED STONES IN ESTONIA
}

\section{Andres Tvauri}

\section{INTRODUCTION}

The cup-marked stone is a stone that has one or several mainly round-bottomed small cup-marks with the diameter of 3-10 cm (most often 4-7 cm) and the depth of 0.5-2 cm chipped into it. In exceptional cases the cup-marks can also be with a pointed or oval bottom. The cup-marked stones differ from offering stones, used until the past and even this century, which sometimes have one or two large offering pits.

In the present research two main problems concerning the cupmarked stones will be discussed: when were the marks made on the stones, and why. As source material, lists of archaeological sites in the archives of the National Board of Antiquities of Estonia and on the data in the topographical archives of the Department of Archaeology of the Institute of History have been used.

\section{HISTORY OF RESEARCH}

The first to mention the cup-marked stones in the Estonian printed sources was J. B. Holzmayer, the teacher at Kuressaare Gymnasium, in 1873. At that time the cup-marked stones in Estonia, as well as in the neighbouring Finland and Sweden were classified under the concept of "offering stones". So, Holzmayer in his book Osiliana (1873), a work about the popular culture of Saaremaa, wrote about the Tumala "offering stone" with cup-marks at Pöide, comparing it with similar stones in Sweden.

The first person to write in Estonian about the "offering stones", with cup-marks was the school teacher and amateur archaeologist Jaan Jung (1835-1900). He was the first to register the archaeological sites in Estonia, with the help of an extensive network of collaborators; he also started to publish list of archaeological sites in his Muinasaja teadus eestlaste maalt (Jung 1898, 1899 and 1910). 
Jung thought, as many did at that time, that the small cup-marks on the stones were offering basins.

In 1921-1927 the archaeological sites in Estonia were inspected and registered according to parishes with the help of grant-aided students. In the course of the work a great number of cup-marked stones were discovered. While in 1921 about a score of cup-marked stones were known in Estonia, by 1925 already 95 certain and 29 dubious cup-marked stones had been found.

The first Estonian treatise dedicated specifically to offering stones was written by folklorist Richard Viidalepp; the work Iseloomustavat Eesti ohvrikividest ("The characteristic traits of the Estonian offering stones") was published in 1939 and 1940. Until the very recent years, this work has been the most comprehensive treatment of the cup-marked stones, regarded at that time as offering stones. In the first 2 decades after World War II no studies concerning cult stones followed. The situation did not change until the 1960s, when the archaeological sites became again state-protected and therefore they were also searched actively. So the number of known cup-marked stones skyrocketed. The pioneer searcher for cup-marked stones is Oskar Raudmets, an amateur archaeologist, who began a systematic search for archaeological sites in the parish of Jüri in the neighbourhood of Tallinn. In the second half of the 1960s the post-war generation of Estonian archaeologists also started to look for cup-marked stones during their archaeological field-walking.

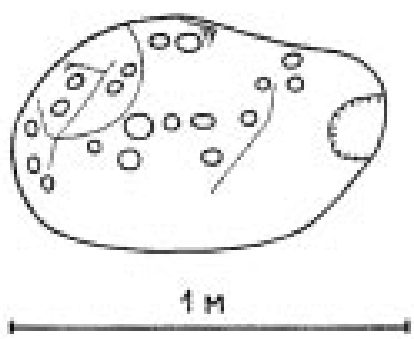

Figure 1. The cup-marked stone accidentally found from a stove dating to the Viking Age. Aindu settlement, Viljandi parish, Viljandi county (Valk 1993).
In 1972 Vello Lõugas published an article concerning cup-marked stones, which was a new approach in the subject. Lõugas was the first to make a distinction between the Estonian offering stones and cup-marked stones as quite different types of archaeological sites both with regard to their function and age. 
The surroundings of a cup-marked stone were first archaeologically excavated in the village of Kaseküla, Hanila parish, in 1973. So far the surroundings of 20 cup-marked stones have been excavated. Nothing has been found that is linked with the cup-marks. Since the last research dealing with these archaeological sites in general (Lõugas 1972), the number of known cup-marked stones has multiplied nearly seven times and is about 1750 at present.

\section{CUP-MARKED STONES}

\subsection{The Distribution of Cup-Marked Stones}

\subsubsection{Estonia}

Most of the Estonian cup-marked stones are situated in the North Estonian districts of Harju-, Järva- and Virumaa (Figure 2). These three districts have $90 \%$ of the total number of the Estonian cupmarked stones. The districts of Saaremaa and Läänemaa count 93 cup-marked stones. In the districts of South Estonia there is information of only 54 stones. On Hiiumaa, the fourth greatest isle in the Baltic Sea, not a single certain cup-marked stone has been found.

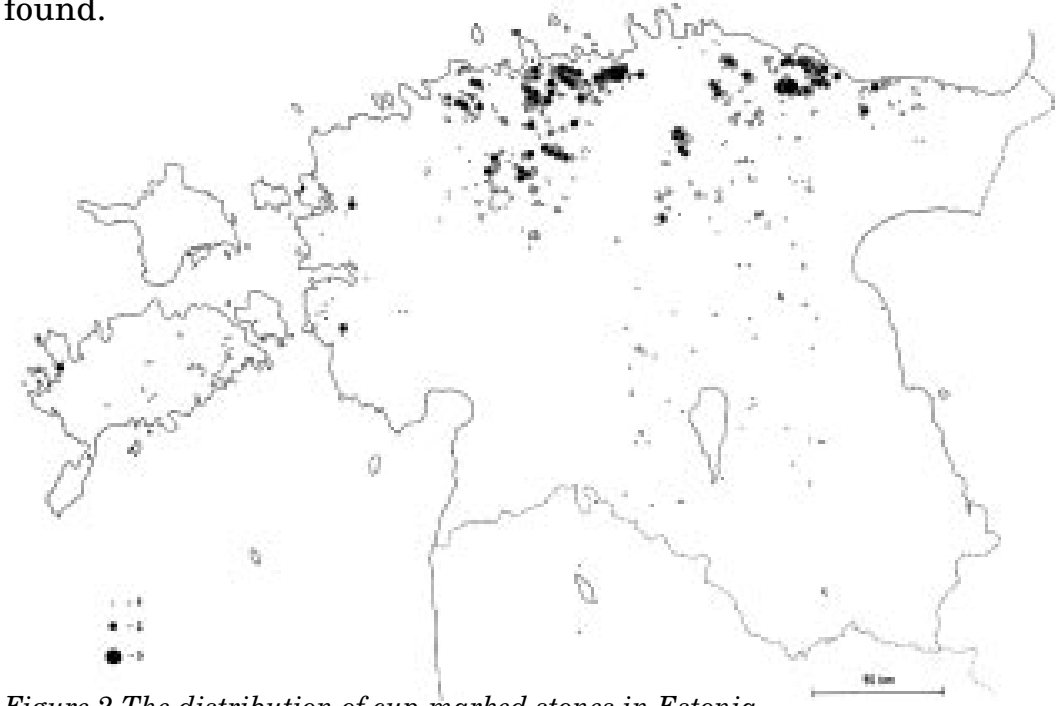

Figure 2.The distribution of cup-marked stones in Estonia. 
The number of cup-marked stones found from Kuusalu parish is also large, consisting of nearly 125 stones. In fact, Kuusalu and its nearest vicinity is one of the richest regions in cup-marked stones in Estonia. More than 50 cup-marked stones have been taken under national protection on the premises of this village only. However, the majority of the Kuusalu cup-marked stones has probably been destroyed. The owner of Kapa farm in Kuusalu village has told Gustav Vilbaste that at the end of the 19th century he had destroyed out of pure ignorance nearly 70 'offering stones with cupmarks' while clearing his fields from stones (Vilbaste 1956b: 57). Approximately 50 cup-marked stones have been found on the premises of the neighbouring villages Vaikla, Kiiu, Allika and Sõitme. The easternmost cup-marked stones in Harjumaa county are located on the premises of Hirvli village; in the area stretching further east to Kadrina parish in Virumaa county no cup-marked stones have been found. No cup-marked stones have been discovered in either the north-eastern part of Kuusalu parish, around the village of Muuksi where is the largest Early Iron Age stone burial place in Estonia with more than 80 stone graves (Vassar 1938; Lõugas \& Selirand 1989: 156-157), or in the surroundings of Uuri village where both stone graves as well as tarand-graves have been discovered (Moora 1977).

Jüri parish, south-east from Tallinn, with its more than 130 stones is also one of the richest regions in cup-marked stones in Estonia. The largest number of cup-marked stones have been discovered on the premises of Assaku and Lehmja villages. Also, one of the stones with 405 cup-marks which is the largest number of cup-marks counted in Northern Europe, Assaku Nõiakivi (Assaku Witch Stone) is located in the village of Assaku.

More than 50 cup-marked stones have been found in Harju-Jaani parish, the number of found cup-marked stones in Kose parish is approximately 70 . Also, several ancient settlement sites and burial places have been discovered in the vicinity (Mandel 1983).

In Keila parish, north-west from Tallinn more than 120 cup-marked stones have been found. Most of them are located east from the Keila River. So far no cup-marked stones have been discovered from Risti and Harju-Madise parishes, in the western part of Harjumaa county. 
The southern part of the historical Harjumaa county largely coincides with today's Rapla county. A number of cup-marked stones have been found there as well. The region differs from other North and West-Estonian stone-localities in that the number of other historical monuments there is very small indeed. The number of Bronze Age and Pre-Roman Iron Age burial places, which are traditionally connected to cup-marked stones, is particularly small in the southern part of Harjumaa county. The ten or so cup-marked stones of Nissi are mainly located in the eastern part of the parish, the 70 cup-marked stones of Hageri parish were found in the villages of Vilivere, Hageri,Adila and Rabivere. In the surroundings ofAngerja and Pahkla village in the eastern part of the parish there is a somewhat isolated site of cup-marked stones. More than 50 cup-marked stones of the Juuru parish are located mainly in the northern part of the parish, mostly around the villages Pirgu and Lõiuse. The majority of the nearly hundred cup-marked stones in Rapla parish are situated in the northern part of the parish around Hagudi village. Another largest site of cup-marked stones in Rapla parish stretches further south, in the villages of Nadalama and Ohekatku.

The two largest cup-marked stone sites of North-Estonia - the Harjumaa county on the one side and the Virumaa and Järvamaa counties on the other - are separated from each other by an area stretching some $20-30 \mathrm{~km}$, where, as mentioned above, no cupmarked stones have been found. No archaeological monuments from the Earlier and Late Iron Age have been found from this marshy and woody area between ancient settlement sites and counties, also, the number of Early Iron Age monuments is very small.

Nearly 600 cup-marked stones, i.e. approximately $35 \%$ of the total number of cup-marked stones in Estonia have been found in Virumaa county. About 520 cup-marked stones were discovered in the western part of the historical Virumaa county, now known as Lääne-Viru county, whereas the majority of them are located in the parishes of Haljala, Kadrina, Rakvere and Viru-Nigula. 220 of the stones are situated in Viru-Nigula parish and about 150 in Rakvere parish. In fact, the distribution of cup-marked stones in the northern part of Viru-Nigula parish is the densest in Estonia on the premises of Kutsala village alone, more than 40 cup-marked stones have been found; nearly as many have been found in Pada 
village. The large number of stones found in Rakvere and ViruNigula parishes may be partly caused by the fact that during the end of 1970s and the beginning of 1980s, the search for cup-marked stones and other archaeological findings in the area was carried out systematically because of the archaeological inspection for the prospective phosphorite pits (Lavi \& Mandel 1985).

About 80 cup-marked stones have been found in the eastern part of Virumaa, today's Ida-Viru county. As compared to the stones discovered from Lääne-Viru county, the number is rather small. The scarcity of stones could be explained by the lack of systematic search for cup-marked stones in the region (Lõugas \& Selirand 1989: 228). More than 40 cup-marked stones of this region are located in Lüganuse parish, the largest sites are in the vicinity of Aa estate and the villages of Erra and Maidla, south from the estate.

Approximately 120 stones are known from Järvamaa county, more than 70 of them are located in Ambla parish. More than 30 of the Ambla cup-marked stones are situated on the relatively restricted area around the villages Läste, Rägavere and Pruuna, a number of cup-marked stones have also been found in Ambla and Jõgisoo villages. The cup-marked stones of Järva-Jaani parish are situated mainly in the villages of Allikjärve, Roosna-Alliku, Valasti, Jalgsema and Karinu. A significant stone site in the southern part of Järvamaa is located in Koordi village, the parish of Peetri with its more than 13 cup-marked stones. Three southernmost cupmarked stones of Järvamaa county are located in Väätsa, Türi parish.

Nearly 60 cup-marked stones have been found on the islands of Saaremaa and Muhu. The number might be even larger, as no such systematic search for cup-marked stones have been carried out there than, say, in Harjumaa or Lääne-Virumaa county. The distribution of cup-marked stones in Saaremaa is the densest in Kurevere (Kihelkonna) village where their number is 10 . Two assumedly westernmost cup-marked stones in Estonia are situated on the island of Vilsandi; these were discovered by Vello Lõugas in 1974 (Lõugas 1995: 76-77). Quite a number of cup-marked stones are situated in the eastern part of Saaremaa, the parishes of Valjala and Pöide (Photo 1). Only two cup-marked stones have been found on the island of Muhu, and one of them was destroyed already at 


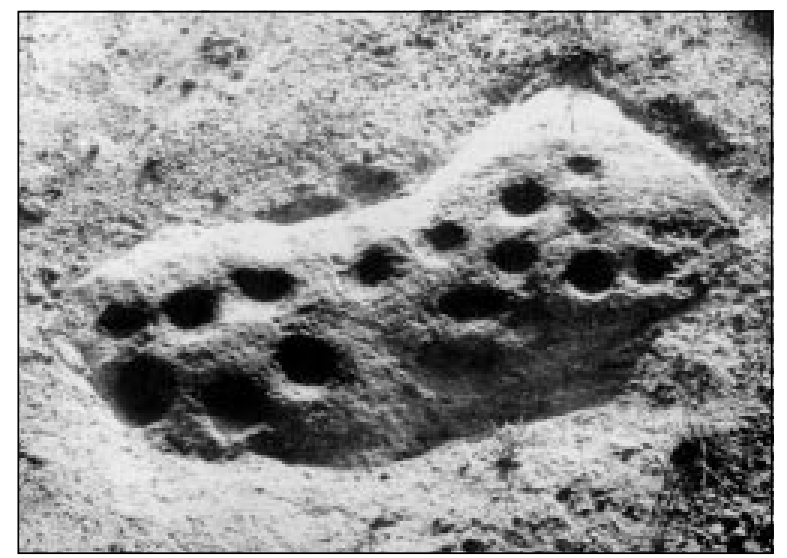

Photo 1. Cup-marked stone in Tumala, Saaremaa. Photo by E. Väljal 1984.

the end of the last century (Lõugas 1995: 77). Interestingly enough, no cup-marked stones have been found in the area of Võhma and Paatsa village in Mustjala parish in Saaremaa which are famous for their large number of other archaeological monuments, and in the relatively wide area in the western part of the island. For a long time no cup-marked stones were found from the Sõrve peninsula either, whereas the area was rich in Iron Age burial places. In 1995 Vello Lõugas succeeded in finding two cup-marked stones at the edge of a large stone formation between Easte and Kaugatuma villages. One of the stone had only few cup-marks but the other had over 60 marks.

30 cup-marked stones altogether have been found in two different regions of Läänemaa county. More than 10 stones are located around the villages of Auaste, Uugla and Taebla in Lääne-Nigula parish east from the town of Haapsalu. The second group of Läänemaa cup-marked stones is situated in the parishes of Hanila and Karuse, south from Matsalu Bay. The majority, i.e. more than ten of them are located in the vicinity of Linnuse village in Karuse.

Few cup-marked stones have been found in South-Estonia. Only 54 stones altogether have been found in Viljandi, Tartu and Võru counties. Most of them are located in the northern part of Tartu and Viljandi counties. 
25 cup-marked stones have been found in Viljandi county. The area richest in cup-marked stones in the county is in the vicinity of Kuiavere and Tääksi villages in Suure-Jaani parish, where the number of stones is six. Another cup-marked stone is situated quite nearby in the villages of Kuhjavere and Võhma. Four cup-marked stones have been discovered in Aidu village, the parish of Paistu. The neighbouring villages Koera (Sultsi) and Muri have one stone each.

24 cup-marked stones have been found in Tartu county, they are dispersed over the parishes of Laiuse, Torma, Palamuse, Kursi, Äksi, Puhja, Nõo and Kambja.

Only four cup-marked stones are known and taken under protection in Võru county: one of them is in Valgjärve village, Kanepi parish and the other three quite close to each other in the villages of Viru and Kõrgepalu, Rõuge parish. The stones of Rõuge are the southern- and south-easternmost cup-marked stones in Estonia.

\subsubsection{Cup-Marked Stones And Rocks Around the World}

In the prehistoric times small round cup-marks were made in stones or rocks in Scandinavia, on the British Isles, in Northern Germany, on the coasts of the Mediterranean, in the mountains of Caucasus, Altai and Sayans, as well as in the Near East. Similar cup-marks are to be found in India, Siberia, China and even in Australia, North and South America.

However, the greatest number of cup-marked stones and rocks are located in North Europe - in Denmark, Norway, Sweden, Finland (Figure 3), Estonia and Northern Germany. Only about 20 cupmarked stones are known east of Estonia, in the Novgorodian Land of Russia. East of the Valdai uplands no cup-marked stones have been found. In Latvia only 5 certain cup-marked stones have been found so far, and some dubious ones (Figure 4). From Lithuania data of 18 stones are available. 
Figure 3. The distribution of

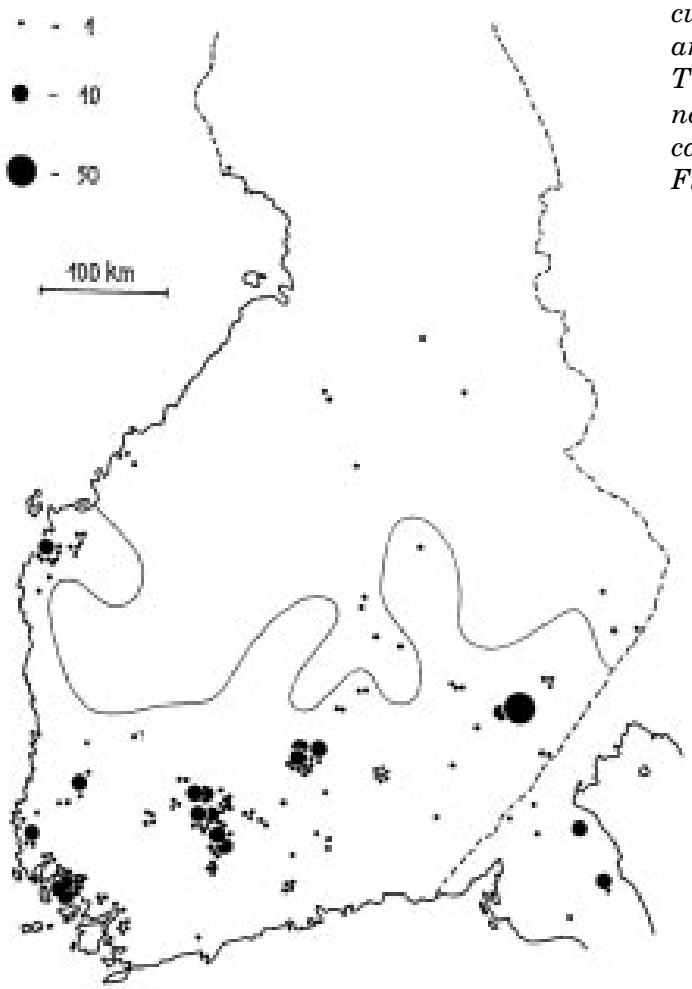
cup-marked stones in Finland and the Isthmus of Karelia. The map shows also the northern boundary of the socalled "bread grain zone" in Finland (Solantie 1988).

Figure 4. The distribution of cup-marked stones in Latvia.

1 - cup-marked stone; 2 - supposed cup-marked stone.

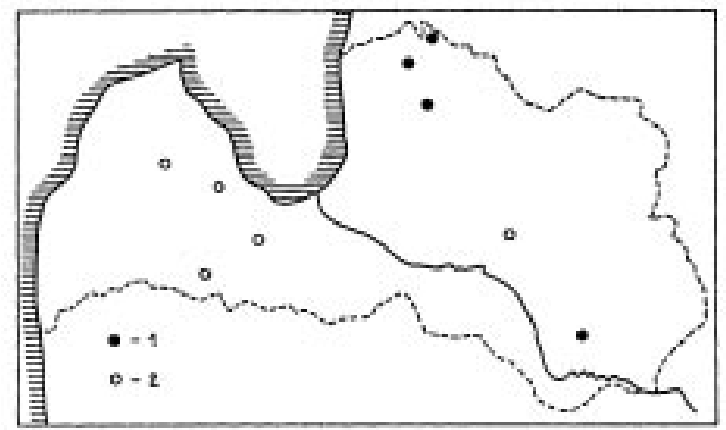




\subsection{The Appearance of Cup-Marked Stones}

\subsubsection{Stones}

Almost all Estonian cup-marked stones are crystalline erratic boulders transported by the glacial sheet from Fennoscandia during the last Ice Age (Photo 2). The only exception here are the two cupmarked limestone rocks on the island of Vilsandi. Vello Lõugas has counted six cup-marks on one of them and four on the other (Lõugas 1995: 77). In the whole Northern Europe, cup-marks have been carved mostly in solid crystalline rocks and only occasionally in limestone or sandstone. Cup-marked limestone rocks have been found in Gotland, for example (Hasselrot \& Ohlmarks 1966: 214221). In rare cases cup-marks have been also carved in sandstone in Sweden (Kaliff 1995: 241).

The size of Estonian cup-marked stones varies greatly. The larger stones might be the size of a sauna, the smaller ones could be lifted by a man. Probably the largest cup-marked stone in Estonia is the Lehmja-Loo Suurkivi in Jüri parish (Harju county 2040): its circumference is 23 metres and the height 3 metres (Raudmets 1967: $60)$. As already mentioned, the smallest cup-marked stone was dis-

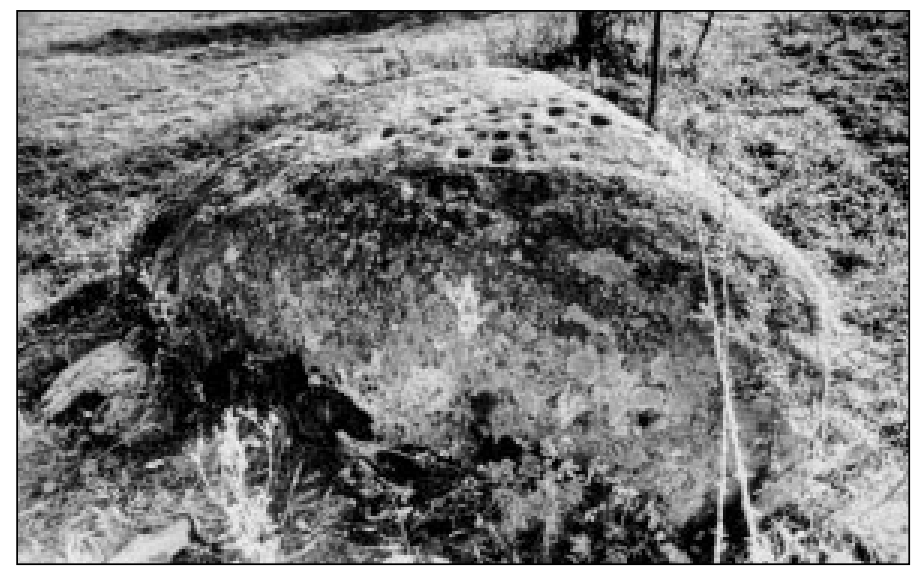

Photo 2. Cup-marked stone in Jõelähtme, Harju county. Photo by E. Väljal 1982. 
covered from the Rannu settlement site with size 10.6 × $9.1 \times 3.6$ $\mathrm{cm}$. This 'pocket-size' stone has two regular and well-preserved artificial cup-marks with the circumference of 4.1-4.4 cm and depth $0.5 \mathrm{~cm}$.

Similarly to the boulders, the majority of Estonian cup-marked stones are less than 1 metre in height. The upper part of the stone is usually relatively even, horizontal or somewhat sloping. Cupmarks are often made in the upper part of the stone, sometimes, however, they could be found elsewhere. Apparently, cup-marks have not been carved consciously into stones of certain size or shape.

\subsubsection{The Number of Cup-Marks}

The author of the current article was able to determine the number of cup-marks of 986 stones out of the nearly 1750 cup-marked stones in Estonia. No archaeological certificates have been issued for the rest of them, also their number has not been mentioned in any other source.

$15.5 \%$ of the Estonian cup-marked stones have only one cup-mark, $10 \%$ have two cup-marks and $11 \%$ three cup-marks. $72 \%$ of the Estonian cup-marked stones have up to ten cup-marks. The mentioned proportion could be applied to the distribution of cup-marked stones in the whole Northern Europe. In Finland, for example, 16\% of the cup-marked stones have one mark, $11 \%$ have two cup-marks and $7 \%$ three cup-marks. $67 \%$ of the cup-marked stones of Finland have up to ten cup-marks (Tvauri 1995: 29). In Västergötland county in Sweden the percentage of stones and rocks with up to ten cupmarks is $58.2 \%$. Here I have not considered the cup-marks found on the petroglyphs and stone blocks of burial places of Västergötland (Selinge 1989: 135). Proportionally, the number of stones with fewer cup-marks might be even larger: the less cup-marks a stone has, the harder it is to notice it.

Stones with more than a hundred cup-marks are rare in Estonia; only 11 have been discovered so far. The number of stones with numerous cup-marks is the largest in Jüri parish in Harjumaa county: the stone Assaku Nõiakivi (Photo 3) has 405 cup-marks, a stone in Lehmja village has 150 marks, a stone in Jüri settlement 




Photo 3. The stone "Assaku nõiakivi” or Assaku Witch Stone with 405 cup-marks. Photo by E. Väljal 1980.

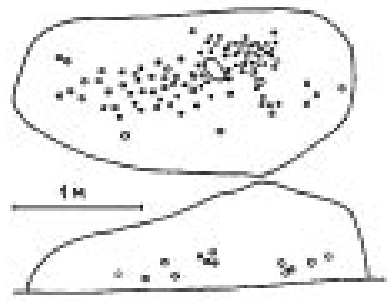

Figure 5. The cup-marked stone at Nabula, Jüri parish, Harju county (Harju county 2387). The stone has at least 107 cup-marks, some of them on the vertical side-face. has 102 cup-marks and a stone in Nabala village has 107 cup-marks (Figure 5; Harju county 2387). 115 cup-marks have been counted on a stone in Koila village in Jõelähtme (Harju county 192-k). One stone in Urvaste village, Kose parish has at least 108 cup-marks and one in Jalase village, Rapla parish at least 160 cup-marks (Tamla 1994: 43).Two stones with more than a hundred cup-marks are known in Viru-Nigula parish, Viru county: a stone with 111 cup-marks in Tüükri village (LääneViru county 560-k), and another stone with 112 cup-marks on the premises of Vasta village (LääneViru county 382-k). In 1979, 263 cup-marks were counted on a stone in Aidu village (merged with Maidla village) in Lüganuse parish (Lõugas1995: 65). A stone with 202 cup-marks is situated in Erra, the neighbouring village of Maidla. It is quite remarkable that in Estonia the stones with numerous cup-marks are generally found 


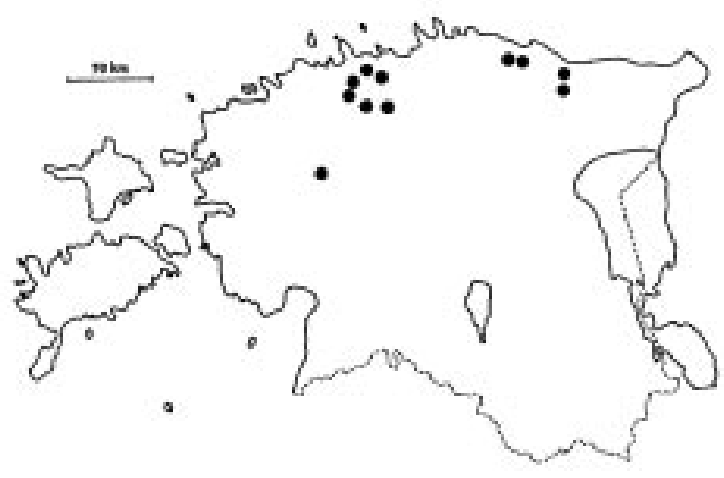

Figure 6. The distribution of stones with over a hundred cup-marks in Estonia.

in areas where the number of cup-marked stones is larger (Figure $6)$.

In Finland the stones with more than a hundred cup-marks are quite rare as well. There are only two of them - one with 108 cupmarks (Saukkonen 1985) and the other with 136-139 cup-marks (Saukkonen 1984). Both are located in Häme, one of the richest areas in cup-marked stones in Finland.

Compared to the number of cup-marked stones and rocks in general, the stones with numerous cup-marks are relatively rare in Sweden as well. Stones with more than 400 cup-marks are great rarities. The Härkeberga " $\mathrm{A}$ " cup-marked rock in Uppland is probably the richest in cup-marks in the whole Northern Europe with its nearly 500 cup-marks (Coles 1995: 21).

The information suggests that the early people made cup-marks rather than cup-marked stones. In Estonia as well as in the rest of Northern Europe, the number of cup-marks carved into a stone during a certain period of time was not predetermined. The extremely large number of cup-marks on a single stone might be the result of the lack of other stones in the closest surroundings. Probably, it was also comfortable to make cup-marks into one particular stone, or it was a matter of habit. 
Therefore, the archaeological unit is a cup-mark rather than the stone on which it is made. Approximately 10,560 definitely artificial cup-marks have been counted on the cup-marked stones of Estonia. Considering the fact that the cup-marks have been counted only on about a thousand stones out of the 1750 cup-marked stones of Estonia, we might assume the total number of cup-marks on known cup-marked stones of Estonia to be 17,000-18,000. In comparison we might note that in Finland 3.800 cup-marks have been counted on about 300 stones, whereas the total number of cupmarks on all the cup-marked stones might be approximately 4,560 (Tvauri 1995: 31). Nearly 30,000 cup-marks have been counted on the cup-marked stones and open rock-faces in Uppland, Sweden's richest region in archaeological monuments (Coles 1995: 20). By 1985 more than 27,000 cup-marks had been counted in Bohuslän, one of Sweden's richest areas in rock-carvings (Bertilsson 1989: 102).

According to the data gathered in 1994, the distribution of cupmarks in Estonia is the following:

\begin{tabular}{l|ccc} 
& $\begin{array}{l}\text { The number of } \\
\text { known cup- } \\
\text { marked stones }\end{array}$ & $\begin{array}{l}\text { The number } \\
\text { cup-marks }\end{array}$ & $\begin{array}{l}\text { The assumed total of } \\
\text { cup-marks on all } \\
\text { known cup-marked } \\
\text { stones }\end{array}$ \\
County & 870 & 5800 & 8900 \\
\hline Harju county & 600 & 2800 & 6500 \\
Viru county & 120 & 735 & 1100 \\
Järva county & 59 & 415 & 670 \\
Saaremaa island & 30 & 275 & 375 \\
Läänemaa & &
\end{tabular}

The number of cup-marks might be associated with the onetime population density in a given region, i.e. the number of land-users in the area, or the contemporary economic potential of the region. This assumption is supported by the corresponding proportion between the cup-marks on the cup-marked stones in Estonia, Finland and two Swedish counties. Still, the interpretation of the number of cup-marks remains questionable until it is possible to determine the age and the precise function of the cup-marks. 


\subsubsection{The Position of Cup-Marks}

Most of the cup-marks on the Estonian stones are located on the upper side, horizontal or sloping surface of the stone, i.e. in places where it was most comfortable to make them.

On about $4 \%$ of the cup-marked stones the cup-marks have been made on vertical surfaces (e.g. Photo 4). The majority of such stones appear to be in their original places and in the original position, as they are often quite large and fixed firmly in the ground. A stone in Parasmäe village, Jõelähtme parish with 58 cup-marks has most cup-marks on the vertical surface (Harju county 2293). In Rebala village in the same parish there is a stone with 54 cup-marks (Harju county $187-\mathrm{k}$ ) which are also made into vertical surface. Cup-marks on vertical and strongly sloping sides of stones and open rock faces are common in the whole distribution area of cup-marked stones. This proves that cup-marks were not made for a specific purpose, for example such as offering.

There is no evidence of the relation between the position of cupmarks and points of compass. The description of stones suggests that most of the cup-marks are located on the sides slightly sloping towards south-west, south, south-east or east, i.e. on the sunny sides of the stone. Still, since there is plenty of examples which

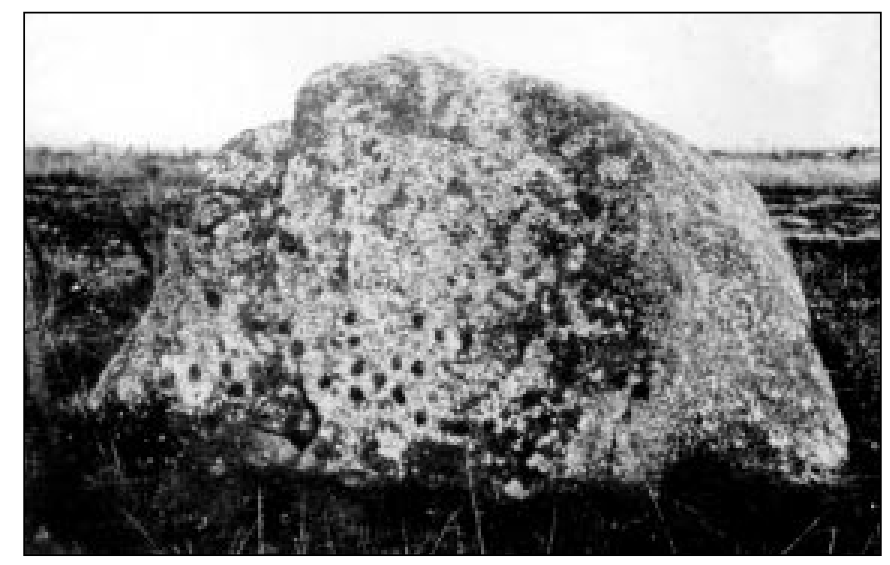

Photo 4. The cup-marked stone of Sepa at Parasmäe (Jõelähtme parish). Most of the cup-marks are on the vertical side. Photo by E. Väljal 1984. 


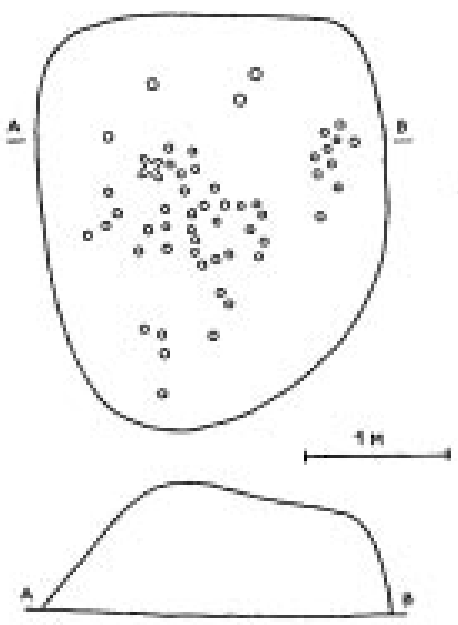

Figure 7. The cup-marked stone with 53 cup-marks and a cross in the village of Sooaluse, Rakvere parish, Viru county.

show the opposite, we have no v reason to assume that it has been a conscious preference of the cup-makers.

The position of cup-marks on the Estonian cup-marked stones is almost always random - they are either scattered or located in indistinct groups (Figure 7). On nine stones only cup-marks form rows of 4-15 marks. It might be explained by the shape of the stone if the row of cup-marks is located on the sharp ridge-like upper part. Similar rows of cup-marks have been found for example in Salumäe village, Harju-Jaani parish (Harju county 326-k), in Koila (Harju county 391-k) and Parasmäe villages, Jõelähtme parish (Harju county 409-k and 2295), Kodasema village, Keila parish (Harju county 5-k) and Aidu village in Paistu parish (Viljandi county 1804). Compared to the Scandinavian countries the number of rows of cup-marks on the Estonian stones is relatively small. Of course, there are more cupmark figures in Scandinavia as well. The most famous row of cupmarks in Sweden could be seen on a Vitlycke rock-carving in Bohuslän, where about 68 cup-marks form a regular row (Hasselrot \& Ohlmarks 1966: 89). In Finland the number of cup-mark rows is relatively bigger than in Estonia: in the town of Turku and its vicinity, cup-marks form a double row in even four cases: one of the Turku's cup-marked rocks has 28 cup-marks in a double row (Asplund 1990).

Often, the makers of new cup-marks have not considered the earlier marks on the stone: on several occasions older cup-marks have been ruined by making a new one. Such stones could be found in Harju region, for example (Rapla county 1556, 112-k, 115-k, 185-k, and a stone with 160 cup-marks in Jalase village). Thus, cup-marks were considered neither taboos nor 'sacred'. Apparently, the proc- 
ess of making a cup-mark was most significant, and the cup-mark was for "single use" only.

\subsubsection{The Shape and Size of Cup-Marks}

The diameter of the artificial cup-marks on the Estonian cupmarked stones is generally $3-10 \mathrm{~cm}$ (most often $4-7 \mathrm{~cm}$ ) and their depth $0.5-5 \mathrm{~cm}$. The size and degree of finish of the marks varies even on the same stone. Therefore we must assume that cup-marks were made by different people and possibly also during a longer period of time.

Cup-marks are mostly round marks "as if made in the stone by turning a heel", and "of the size of the top of an egg" (Jung 1898: 187; Viidalepp 1940: 18). The bottom of the cup-mark is often smoothed and therefore clearly visible on the otherwise rugged surface of the stone. Sometimes the bottom of the cup-mark is also uneven, but in most cases it is impossible to determine whether it has been caused by the weathering of the stone or the bottom was made uneven. The cup-mark bottom is more exposed to weathering than the rest of the surface because the frozen rainwater accumulated in the cup-mark might destroy the stone.

The artificial cavities of cup-marks are not necessarily roundshaped and with a smooth curved bottom. In Estonia, at least three cup-marked stones have funnel-shaped cavities. A stone in Saunja village, Jõelähtme parish has 13 cup-marks, one of them is coneshaped (Harju county 319-k). The village of Sooaluse in Rakvere parish has even two such stones. One of the stones has 20 cupmarks, one of which is cone-shaped: the diameter of this round cavity is $4.5 \mathrm{~cm}$ and depth $0.7 \mathrm{~cm}$ (Lääne-Viru county 96-k). The second Sooaluse stone has 47 cup-marks, whereas one has a funnel-shaped bottom (Lääne-Viru county 91-k). Cone-shaped cupmarks have been found on few cup-marked stones in Finland as well (Tvauri 1995: 33).

At least 27 Estonian cup-marked stones are known to have oval cup-marks (Figures 8-9). That is the number of stones which "definite" oval cavities are also mentioned in their certificates. Their number, however, is estimated. In most cases it is almost impossible to determine whether the cavity was originally made oval, or it 




Figure 8. The distribution of stones with oval cup-marks in Estonia.



Figure 9. Stone with oval cupmarks in Vana-Kaiu village, Juuru parish, Harju county. is weathered into an oval mark, or it is merely a cavity that has formed in the merging of two neighbouring cup-marks. The oval cavities vary in size: the length is $6.5-15 \mathrm{~cm}$, width $3.5-7 \mathrm{~cm}$ and depth $0.8-3 \mathrm{~cm}$. The width of an oval mark is usually about a half or one-thirds of its length (e.g. Lääne-Viru county 116k, 253-k, 367-k, 415-k, 595-k, and Rapla county $32-\mathrm{k}, 33-\mathrm{k})$. Oval cupmarks have also been discovered on the Finnish cup-marked stones; also, cup-marks are quite common in Scandinavian countries.

The largest number of oval cup-marks on the Estonian cup-marked stones is three. Interestingly, most cup-marked stones which have oval marks have a larger number of cup-marks as well: only 5 out of the 27 stones have less than then cup-marks. A stone with oval cup-marks in Urvaste village, Kose parish, Harju county has at least 108 cup-marks. The Vihavu village cup-marked stone in Puhja parish, Tartu county has 94 round and 2 oval cup-marks (Tartu county 1669). A stone in Aresi village, Rakvere parish has 93 cup- 
marks of which 2 are oval (Lääne-Viru county 253). A cup-marked stone in Karinu village in Järva-Jaani has 60 round and two oval cup-marks (Järva county 49-k). Quite exceptional is a stone in Tade village, Kose parish, Harju county, which only cup-mark is ovalshaped (Harju county 497).

A cup-marked stone in Joa-Suurküla village, Keila parish with 15 cup-marks has an additional cavity which resembles a curved wiener (Harju county 232-k). Such a shape is extremely rare on the Estonian cup-marked stones, whereas in Sweden, for example, an analogous shape in combination with ordinary cup-marks figures often in petroglyphs (Burenhult 1980: 88-89).

Cup-marks are sometimes linked by a channel or a groove carved into the stone. Similar cavities are known on 23 Estonian cupmarked stones (Figure 10). The number of cup-marks linked by channels might be even larger, as people providing descriptions might have failed to notice them. Generally, one stone has a single linked pair of cup-marks; only six stones have more than one channel. Two pairs of linked cup-marks could be seen in Vasta village, Viru-Nigula parish (Lääne-Viru county 152-k), Linnuse village, Karuse parish, Läänemaa region (Lääne county 71-k), Tahula village, Kaarma parish in Saaremaa (Saare county 69-k; Lõugas 1995: 72 ) and on a stone on Tumala hill in Pöide parish. One channel of the Tumala cup-marked stone forms a right angle (Lõugas 1995: 81).

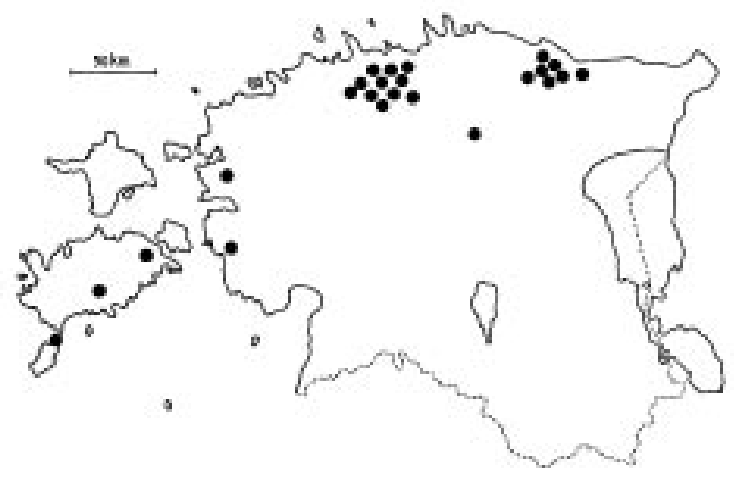

Figure 10. The distribution of channel-linked cup-marks in Estonia. 
Channel-linked cup-marks occur most often on stones with numerous cup-marks: of the 23 stones with channel(s) only three have less than ten cup-marks (Harju county 245-k; an unregistered stone in Kirdalu village, Hageri parish; Lääne-Viru county 182-k). Of all the cup-marked stones with channels, the number of cup-marks is the largest on the stone Assaku Nõiakivi with 405 cup-marks, a stone in Tüükri village, Viru-Nigula with 111 cup-marks (LääneViru county 560-k) and a stone in Vasta village in the same parish with 87 cup-marks, that has two pairs of channel-linked cup-marks (Lääne-Viru county 152-k). Two pairs of channel-linked cup-marks are also on the stone with 54 cup-marks on Tumala hill in Pöide parish (Lõugas 1995: 81). Also, the above-mentioned stone with at least 108 cup-marks in Urvaste village, Kose parish and the stone with 87 cup-marks in Rebala village, Jõelähtme parish have both channel-linked cup-marks (Harju county 185).

Cup-marks linked by channels have been found in Finland as well as in Scandinavian countries, but also in Asia (Aspelin 1895: 3). And although channels have been found over a large area, they occur only on about $1.3 \%$ of Estonian and $2 \%$ of Finnish cup-marked stones.



Figure 11. The cup-marked stone with channels and a bow-shaped carving in the village of Valasti, Järva-Jaani parish, Järva county.
Most original channels were discovered on a stone with 30 cup-marks in Valasti village in Järva-Jaani (Figure 11). It has six channels and seven of its cup-marks are linked by several channels. As many as three channels run in different directions from one cup-mark. Two cup-marks form the starting points for channels which do not end in another cup-mark but descend down the $45^{\circ}$ sloping edge towards the ground. The well-preserved and clearly visible grooves of the Valasti stone are 3-4 cm wide and 1-2 cm deep. Besides the cup- 
marks, a bow-shaped figure has been carved into the stone; its relation with cup-marks and channels is unclear, though (Järva county 2076).

A stone in Viru village, Rõuge parish, Võru county has 35 cup-marks and, besides that five annular cavities. It is not certain whether they are just unfinished cup-marks or were the cavities intentionally given in such original shapes. The same stone has three additional quadrangular cavities with $4 \mathrm{~cm}$ sides and the depth of $4 \mathrm{~cm}$ (Figure 12; Võru county 76-k).

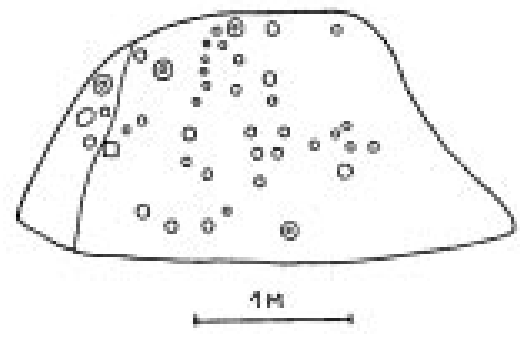

Figure 12. The cup-marked stone with quadrangular and rounded marks in the village of Viru, Rõuge parish, Võru county.

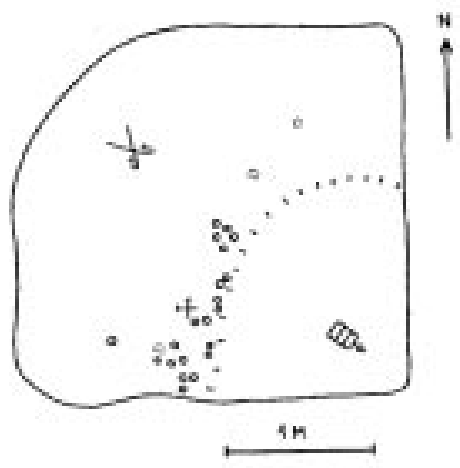

Figure 13. "Lauritsakivi" or The St. Lawrence Stone at Kuusalu, Harju county, with a medieval landmark.

According to the 1925 parish register description, Lauritsakivi (the St. Lawrence Stone) at Kuusalu (Figure 13) has besides ordinary cup-marks also two small annular cavities, $5 \mathrm{~cm}$ in diameter (Parmas 1925).

A cup-marked stone in Nugeri village, Viru-Nigula parish has besides three round-shaped cup-marks also two triangular cavities. The latter, however, are weathered to a degree, where they cannot be considered man-made for certain (Lääne-Viru county 372-k).

Two stones from Martna parish and one from Ridala parish in Läänemaa is known to have only quadrangular cavities (Viidalepp 1940: 20). A stone 200 metres east from Kropkuva farm near Helbi village, Meremäe parish, Setumaa has nine artificial cavities with $1-2 \mathrm{~cm}$ in diameter and two cavities with $3-4 \mathrm{~cm}$ in diameter. They 
resemble the cup-marks on cup-marked stones but are considerably smaller (Valk 1994a). Still, the stones under discussion are not necessarily related to cup-marks.

So far no tools for making cup-marks have been found in Estonia. The only object that has presumably been used for making cupmarks was an oblong stone with a round top and $6 \mathrm{~cm}$ in diameter found from Sõgula, Jüri parish by Oskar Raudmets (Raudmets 1974: 147; 1975: 35).

No tools for making cup-marks have been found in Finland either. In Sweden, however, smaller stones used for making rock-carvings and cup-marks have been found near the petroglyphs (Hasselrot \& Ohlmarks 1966: 16). The cup-marks on Estonian stones seem to be carved with a stone as well: it is quite unlikely that a metal tool was used for this purpose.

In 1980 an archaeologist Ain Mäesalu made an attempt to carve a cup-mark into a stone with a piece of granite rock. It took him about two hours to make a cavity similar to the cup-marks on cupmarked stones. In Sweden, however, a cup-mark was made within a few minutes using a similar technique (Hasselrot 1984: 63).

The time used for making a cup-mark depends probably on the hardness of the cup-marked stone as well as that of the tool used for making the mark. Ain Mäesalu tried to make a cup-mark by rubbing it with another piece of stone, but this method proved extremely difficult and time-consuming. Although it is not plausible that the cup-marks were carved into a stone by rubbing it with another stone, the cup-mark makers might have used it for polishing the surface of the cup-mark. In 1979, locar history researchers tried to make a cup-mark by using red-hot iron and cold water, and it took them about 40 minutes to make a cup-mark (Lauringson 1979: 24). But this method is too complicated and requires so much preparation that it is quite unlikely that it was ever used.

\subsubsection{Other Figures on Cup-Marked Stones}

Sometimes various symbols and figures have been carved into cupmarked stones which cannot be considered the variants of cupmarks. Some of these figures are clearly younger than cup-marks 
and are in no way related to them. Few of the symbols on cupmarked stones might be dated to the same period.

The carvings on the following 16 stones might be dated to the historic time:

1 Lehtse village, Ambla parish (Figure 14; Järva county 876). The stone has a cross and eight cup-marks, and was popularly known under the name Ristikivi (the Cross Stone) (Saarist \& Tõnisson 1986: 22).

2 Läste village, Ambla parish. The stone has a cross and 19 cupmarks (Järva county 61-k).

3 Hageri village, Hageri parish (Rapla county 1539). The stone has two cup-marks and a cross.

4 Kaliküla, Haljala parish (Lääne-Viru county 509-k). The stone has three cup-marks and additional letters $E T$ carved into the surface.

5 Assaku Nõiakivi in Jüri parish. 405 cup-marks, in the centre of a stone there is a cross which shape suggests its belonging to the medieval times. According to Oskar Raudmets there is also number 8 carved into the stone (Raudmets 1964).

6 Lehmja village, Jüri parish (Harju county 2432). A triangle, number 78 and 15 cup-marks have been carved into the stone. The triangle and number 78 suggest that the stone must have served as a landmark.

7 Lehmja village, Jüri parish (Harju county 2422). The stone has a cross and six cup-marks.

8 Lehmja-Loo village, Jüri parish (Harju county 2041). The stone has a cross, number 9 and 15 cup-marks. The cross and number 9 must have served as landmarks.

9 Saue village, Keila parish (Harju county 2396). The stone has a cross and six cup-marks.

10 Kuusalu village, Kuusalu parish (Harju county 659-k). The stone has a central cross and a cup-mark.

11 Kuusalu Lauritsakivi, Kuusalu parish (see Figure 13; Harju county 368). The stone has 20 cup-marks, the figures of two crossed crosiers and a grate on its sides, and also a cross on the top of the stone. The stone is popularly known also as Rajakivi (Path Stone). The grate attributed to St. Lawrence or Laurits. St. Lawrence was the patron saint of Kuusalu church (Jung 
1910: 85-86). Gustav Vilbaste has argued that the stone acquired its function as a landmark in 1418 when the borders between Kuusalu church and Roma Monastery of Gotland were fixed (Vilbaste 1956a). A similar figure of two crossed crosiers is also depicted on the seal of the Roma Monastery (Hermann 1973: 347).

12 Kalmestri, Lüganuse parish (Ida-Viru county $24-\mathrm{k}$ ). The stone has at least four cup-marks and a cross among them.

13 Kassinurme village, Palamuse parish (Jõgeva county 28-k). The stone has 18 clearly visible and few indistinct cup-marks and a small cross.

14 Annikvere village, Põltsamaa parish (Jõgeva county 515). The stone has a letter $W$ carved on the northern side and letters $N W$ on the south-western side. In the centre of a stone there is a cross located so that its northern, eastern and southern branch end in cup-marks (Figure 15). The stone has 22 cup-marks. The cross and letters must have marked boundaries.

15 Sooaluse village, Rakvere parish (see Figure 7; Lääne-Viru county $88-\mathrm{k}$ ). The stone has a cross and 53 cup-marks.

16 Lasnamäe district, Tallinn (Tallinn 2429). The stone originally in the yard of Mustjala farm that got in the way of large blocks of houses and was pulled down, had four cup-marks and also a cross. The stone was a landmark of the medieval Tallinn.

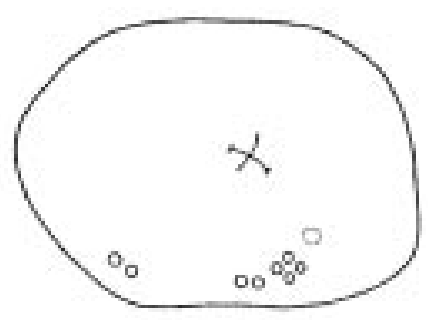

Figure 14. The cup-marked stone that has been used for healing practices in the village of Lehtse, Ambla parish, Järva county.



Figure 15. The cup-marked stone with a carved cross and letters in the village of Annikvere, Põltsamaa parish, Viljandi county. 
Most crosses carved into stones could be dated to the historic period and were probable landmarks. It is also possible that some crosses were made in memory of the deceased (Viidalepp 1940: 24). Also, we cannot quite exclude the possibility that the cross-shaped symbols were carved into the stones at the same time with cupmarks. Crosses and sun discs have been found on cup-marked stones also in Denmark (Glob 1969: 56-58).

Besides crosses, letters and numbers, other artificial shapes have been carved into the cup-marked stones that cannot be related to cup-marks, or dated to a certain period of time:

1 Massu Liukkibi or Läätsikibi, Hanila parish (Lääne county 29). The stones with a sharp ridge and 11 cup-marks has three oval smooth-bottomed cavities in the upper part of its $30^{\circ}$ sloping northern side. The sliding tracks' (lighter trails) descend from the cavities. The diameter of one cavity is 25 , of two others $23 \mathrm{~cm}$. The cavities resemble the artificial cavities of offering stones with larger cup-marks. Even this century people are known to have taken offerings to the Massu cup-marked stone. Also, children are said to have slid down the stone just for pleasure (Laid 1938; Viidalepp 1940: 35).

2 Pirgu village, Juuru parish (Rapla county 129-k). An irregular about $30 \mathrm{~cm}$ long, the maximum of $10 \mathrm{~cm}$ wide and up to $12 \mathrm{~cm}$ deep cavity has been carved into the stone with four cup-marks. The northern corner of the cavity has a drilling hole.

3 Valasti village, Järva-Jaani parish (Järva county 2075). The stone has approximately 30 cup-marks, some of which are linked together by long well-preserved channels (see Figure 11). The stone has also an $18 \mathrm{~cm}$ long and $13 \mathrm{~cm}$ wide bow-shaped carving.

4 Süvalepa village, Palamuse parish (Jõgeva county 549). The stone has 13 cup-marks and an apparently artificial archshaped symbol.According to popular tradition the stone is said to have been used for offering (Jürgens 1921: 29-30).

5 Pärna village, Viru-Nigula parish. In addition to the two cupmarks, the stone has lines carved in its surface that form a grid-like pattern (Figure 16). The depth of the lines is 7-8 $\mathrm{mm}$, and they are partly destroyed due to weathering (Elstrok \& Tamla 1987). 


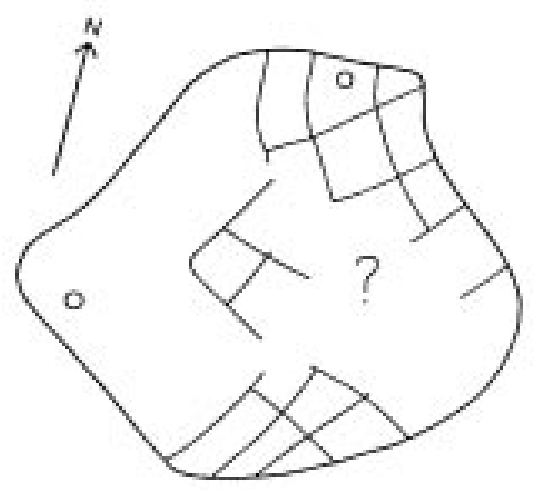

Figure 16. The cup-marked stone with carved lines in Pärnu village, Viru-Nigula parish, Viru county (after Elstrok \& Tamla 1987).

6 Elistvere village, Äksi parish (Jõgeva county 23-k). The stone has at least nine cup-marks and a carved triangle.

Sometimes, drilling holes have been discovered on the cup-marked stones, which suggest that the demolishing of the stone was not completed. At least on two occasions - in Vastja village, Rapla (Rapla county 57-k) and Koordi village in Peetri (Järva county 23-k) the hole has been drilled directly into the ancient cup-mark.

A stone in Kunda, Viru-Nigula parish with 8 cup-marks has been used as a whetting stone. People are said to have whetted their scythe stones on it as late as at the beginning of this century. The stone has a visible oval whetting spot (Lääne-Viru county 1410).

\subsection{Oral Heritage}

In Estonia, a large bulk of oral folk tradition has been gathered on stones, partly also on cup-marked stones. For a long time the local cup-marked stones have been considered offering stones, and therefore we should have a closer look at the relationship between the cup-marks under discussion and the later tradition concerning offering and healing stones.

Sacrifice to stones was very common in Estonia as late as in the 19th century when the collecting of folk belief and tradition was initiated. Even in the 1930s people took offerings to some stones in earnest belief. The offering gifts were left for fairies, but the stones have been used also for healing purposes. These two traditions differ in their nature, but in folk tradition they become so closely interrelated that it is often difficult, if not impossible to regard them 
separately. Some cup-marked stones have also been used for offering or healing purposes. We will first consider the cup-marked stones which are mentioned in more or less authentic accounts:

1 Massu Liukkibi or Läätsikibi in Hanila parish. The stone has 11 cup-marks and three larger artificial cavities. As mentioned before, the stone was used for offering and sliding.

2 Rõhu village, Koeru parish. The stone has three cup-marks. According to folk tradition, an offering fire was made on the stone. The surface of the stone seems crumbled from heat (Järva county 2091).

3 Tumala village, Pöide parish. According to the parish description from 1922, "blood and other things" are said to have been sacrificed to the stone with 60 cup-marks (Tiismaa 1922).

4 Blood is said to have sacrificed also to the other cup-marked stone on Tumala hill (ERA, E I 30 (219).

5 Tääksi village, Suure-Jaani parish. A stone with 14 cup-marks. It is said to be the same stone that according to Jaan Jung was called Tõnni vakk (Tõnn's Bushel) (Veiksar 1982: 28). Originally, the stone is known to have been located in a sacred grove. People made offerings from every fresh-harvested crop, the first milk of a cow and slaughtered animals' meat. During the offering ritual they said: "Tõnn, here's your part!" The custom is said to have been followed as late as at the beginning of the 19th century (Jung 1898: 222-223).

6 Vasara Lohukivi in Viljandi parish (Figure 17) was according to the 1935 parish description used also as an offering stone. People are said to have burnt grains in its cup-marks for sacrificial purposes (Amandus 1939).

Figure 17. The cup-marked stone in the village of Vasara, Viljandi parish, Viljandi county. Used also as an offering stone.

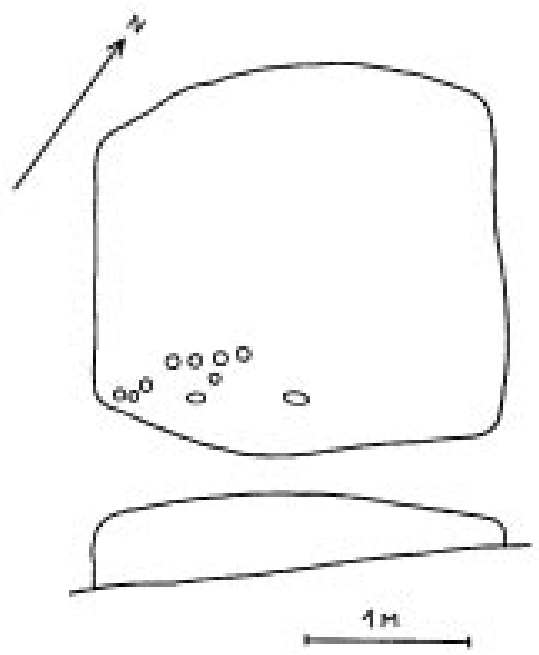


Several cup-marked stones are known in folk tradition or in literature as offering stones, still, it is not certain whether it is the cupmarks that have attributed the stones this meaning. Often there are no direct accounts of offering to a certain stone. For instance, the stone on the field of Hagari farm in Haljava village Harju-Jaani parish was described by Jaan Jung as follows: "There was a large stone with 5 rounded plate-shaped holes where offerings were placed" (Jung 1910: 67). We cannot be certain whether Jaan Jung relied on an authentic account about offering into cup-marks or did he base his assumption on the contemporary concept about cupmarks.

Jung's report on Kuusalu Lauritsakivi appears also dubious: "It is also an old offering stone, as several smaller cavities have been rubbed in its surface for placing offering grains" (Jung 1910: 8586). According to a 1936 account a stone in Kolga, Kuusalu parish was "considered an offering stone by people"; there was also a sacred spring and sacred trees nearby. The Ukukivi with two cupmarks in Viisuküla, Peetri parish was also known as an offering stone (Saarist \& Tõnisson 1986: 22). The authenticity of folk tradition collected today is somewhat questionable as well: a seemingly authentic report might be but a knowledge taken from a book and passed on by several mediators. An account from 1990 said about a destroyed cup-marked stone in Vaida village (Jüri parish): "Every farm had its hole for placing offerings at certain times - in spring at sowing period, in autumn at the harvest. It was either grain or ...". The same source states that offerings were taken also to the Vaida cup-marked stone (Harju county 2462).

Offering stones have sometimes been called also as sacred grove stones in Estonia, which suggests that the stones were once used as offering stones, for healing purposes, or they were originally located in sacred groves. One cup-marked stone called Hiiekivi (the Sacred Grove Stone) is situated in Hageri (Rapla county 1538).

The stones have been widely used for healing in previous as well as in this century. The custom was most common in western Estonia, where various dermatological and eye diseases were cured on stones. Usually, the disease was transferred into coins or salt by touching the sick spot with it. Then the "infected" object was left on the stone. It was believed that the objects on the stone infected 
the one who touched them. (And, several skin diseases that were healed on the stone were probably infectious, too). Thus, the objects left on such stones were rather means of magic transmittance than offering gifts. Eye diseases were cured mostly with the rainwater gathered from the cup-marks and cavities in the stones.

The files of the Estonian Folklore Archives in the Museum of Literature and the topographic archives of the Department of Archaeology in the Institute of History contain reports on at least 400 stones used for offering or healing purposes; only 11 of them are known to have smaller cup-marks. Of all the 1750 cup-marked stones in makes up $0.6 \%$ only.

Of the cup-marked stones that are mentioned in reliable offering reports, the offering gifts are known to have been placed into the cup-marks of only three stones. The majority of the 400 offering stones used in Estonia during the previous and this century have no artificial or natural cavities. The offering gifts were placed simply on the stone or to the ground next to it.

The geographical distribution of cup-marked stones differs also from the distribution of the later offering stones. As already mentioned, the overwhelming majority of cup-marks are located in Harju, Järva and Viru counties, whereas offering stones have been found all over Estonia. The healing stones are most common on the islands of Saaremaa and Muhu, and particularly in Läänemaa region, where the number of cup-marked stones is relatively small.

Thus, the relation of cup-marked stones and offering stones in time and space is so insignificant that the cup-marks and later offering and healing practices cannot possibly be directly related.

Most Estonian cup-marked stones have been discovered by archaeologists; the local villagers have paid little or no attention to the stones. Single stones with numerous cup-marks or stones where the cup-marks are particularly well-preserved have been noticed by people, too. Therefore, folk tradition is partly concerned with the origin of the cup-marks. The cup-marks on a stone in Ahila village, Kadrina parish were popularly called "heel prints" (LääneViru county 299-k). The stone with 160 cup-marks in Jalase village, Rapla parish has been called by local people "the Ott's stone 
with bird-nests" (Tamla 1994: 45). The natural or artificial cupmarks that appear on several stones have been considered as footprints of either Kalevipoeg, Suur Tôll, Vanatühi (the "Old Heathen", i.e. the Devil), God, Jesus Christ, a slave or an animal. An account from Simuna, Virumaa region says about the Liukivi in Salla village that "God has been there, and has left his footprints in the stone" (E 54625). A stone on the grounds of Mikuri farm, Adila parish, Hageri had cup-marks which were considered the footprints of Vanapagan (the Devil) (Eisen 1918/19: 160). And in 1939 the origin of cup-marks on the Tumala stone in Pöide parish was explained by an account saying that "during the sacrifice, the person who performed it had rubbed the stone with a piece of stone or some other tool" (Viidalepp 1940: 23).

The different appearance of some stones have inspired beliefs of witchcraft. For example, Assaku Nõiakivi surely appears odd, as it is covered with cup-marks of different size. But its name, "the Witch Stone of Assaku", might date back to the more recent period, as the stone was found and fully excavated by Oskar Raudmets only in 1964. Before that nobody knew the stone even had cup-marks (Raudmets 1964; 1965). There is a stone in Pärna village, ViruNigula parish with two cup-marks and carved lines, where children were forbidden to go because of the presence of "witchery" (Elstrok \& Tamla 1987). Apparently, the Pärna stone's appeal laid more in its grid pattern of carved lines than the two cup-marks on its surface.

People have talked about the strange stones, saying that a treasure is hidden near or under the stones. According to oral heritage, people had buried silverware near a cup-marked stone in Viljandi parish (Figure 17; Amandus 1939). Also, a popular belief in the last century said that a fortune is hidden under the cup-marked stone on Tumala hill in Pöide parish, Saaremaa. The owner of the estate had the stone removed from its place and had searched the spot himself (Lõugas 1995: 81). A stone near the house of Kulda family in Kurevere village, Saaremaa (Saare county 56-k) has a cup-mark no-one knew about, until it was discovered by Vello Lõugas. Even though, the family members had had a "strange feeling" about the stone and believed it hid a treasure. In fact, at the beginning of 1950s a hole was dug under the stone in search of the fortune (Lõugas 1995: 76). 
Two unique reports on the meaning of cup-marks come from the northern part of Estonia. In 1939 a collector of heritage recorded an account about the cup-marked stone of Kaaruka village, JärvaJaani parish: "Tiny holes appear on the stone: people believed they were the passages through which dead souls entered the other world, as in the past the relatives of the deceased used to carve a small hole in the stone" (ERA II 221, 333 (4), 1939). The same collector has recorded a report about a stone in Kunda, which used to be surrounded by a sacred grove: "The offering stone had holes marking the deceased, who were burnt in the grove, as a close relative of each dead person had an obligation to bore a hole in the offering stone" (ERA II 221, 342 (24), 1939).

Summing up this chapter we must state that the Estonian folk tradition does not reveal the original purpose of the cup-marks. The Finnish folk tradition also lacks original oral heritage about cup-marked stones (Tvauri 1995: 55). The absence of heritage in this particular matter has led us to believe that the tradition of cup-marked stones is an ancient one and has died in people's memories already a long time ago.

\section{THE RELATIONSHIP BETWEEN CUP-MARKED STONES AND LAND CULTIVATION}

Already a brief look at the distribution map of cup-marked stones suggests the relationship between these ancient archaeological monuments and agricultural regions. Hereby I intend to treat the material more thoroughly as this particular aspect has proven relevant for dating the cup-marks and determining their original purpose.

On a global scale, the cup-marked stones and rocks could be found generally in areas with natural disposition for agriculture and also in areas where land-tilling has been practised since pre-historic times. South Scandinavia as well as the southern part of Finland abound in cup-marked stones and rocks; in the northern parts of Fennoscandia, however, with its harsh climate where people have made their living from hunting and reindeer-herding, the cupmarked stones are very rare indeed. 
As mentioned above, the majority of Norwegian cup-marked stones are located south from latitude 66; the same applies to almost all agriculture-related rock-carvings. Only single cup-marked stones could be found north from this line. The northernmost cup-marked stone is the Sandbukt stone on the island of Sørøya in the Arctic Ocean, located about 60 kilometres south from the northernmost point of the Scandinavian peninsula, and north from latitude 70 (Simonsen 1971: 234). Due to the ocean and the Gulf Stream, climate on the Norwegian coast is considerably milder than anywhere else so far north in the world. During the Neolithic era and the Atlantic climatic period the North-European climate was relatively warmer and more humid than it is now: the mean annual temperature was 2-3 degrees higher. Climatically, such change in temperature corresponds to the today's climate in the region $600-960 \mathrm{~km}$ south along the meridian (Rõuk 1992: 22). Even today people cultivate land at the same distance south from Sandbukt cup-marked stone. We might even assume that the cup-marked stone in Sandbukt was associated with the early attempts to cultivate land in North Norway by people arriving from south.

In Sweden, the northernmost cup-marked stones are distributed in the Uppland, Västmanland and Värmland counties. Most probably, the northernmost cup-marks could be found on the Nämsorsen rock-carvings in Ångermanland (Ramqvist 1989: 218). The lack of cup-marked stones in North Sweden might be caused by the fact that the climate eastward from the Scandinavian highland is considerably more continental than in the coastal region of Norway. As continental climate shortens vegetation period, then North Sweden is considerably less favourable to agriculture than the region on the same latitude on the Norwegian coast. Indeed, there are rock-carvings in North Sweden, but they mostly concern hunting and display no cup-marks whatsoever.

In Finland cup-marked stones can only be found in the regions with the most suitable climate for agriculture. Roughly $96.5 \%$ of the Finnish cup-marked stones are located in the sc. bread grain zone (Figure 3) of southern Finland; the northern border of this zone is also the northern border of rye cultivation in Finland (Rantanen \& Solantie 1987). In the wide areas of Lapland and North Finland where the land has never been cultivated or where the 
Finnish peasants arrived as late as in the historic era, no cupmarked stones have been found.

In Finland the climate has changed in the course of time as well, at several times being warmer than it is today. Then again, the ancient agricultural methods were quite primitive, which gives no reason to assume that the land northward from the discussed border was in some way cultivated in pre-historic times.

As compared to Norway, Sweden or Finland stretching more than a thousand kilometres from north to south, the regional differences in the climate of Estonia are rather small. Still, even in Estonia weather conditions vary regionally, which is quite significant for primitive cultivation. In coastal regions where most of the Estonian cup-marked stones are located the climate is much more maritime than in inland; the temperature is more steady, vegetation period and the period without night frosts or permanent snow considerably longer than average. Thus the conditions for primitive land cultivation were more favourable in the coastal regions of Estonia than in inland (EEA 1982: 170).

Observing the distribution of cup-marked stones on landscape we will see that more than $95 \%$ of the Estonian cup-marked stones are situated on former or presently used fields, field edges, hay fields, pastures, home gardens or wastelands. We must bear in mind that the present wastelands are mostly fields and pastures fallowed at the second half of the present century. Only a few cup-marked stones can be found in the woods. Of course, it is much easier to spot cup-marked stones on the open ground, fields and pastures. On the other hand, one cannot fail to notice the systematic lack of cup-marked stones in the fields of new villages from the Middle Ages or later periods. Thus, in Estonia the cup-marked stones are primarily located in the ancient, prehistorically employed cultural landscape.

In Finland the cup-marked stones are also located mostly on cultivated land or in its closest surroundings (Tvauri 1995: 60). The distribution of cup-marked stones in South Savo, one of Finland's richest regions in cup-marked stones, was compared with the 18th century maps toward the land usage of these times, and the results showed that the cup-marked stones where generally located 
in the former assarts, fields or in their immediate vicinity. In the 18 th century $62 \%$ of the total land in the closest vicinity of cupmarked stones was fallow, $36 \%$ under fields and only $1 \%$ totally unused (Kirkinen 1994: 72).

In Estonia the cup-marked stones are spread principally in the zone of gravel carbonate soils. These soils are generally very rich in humus and nutrients originate from the gravel moraine covering the flat limestone elevations and elevated limestone plains of North and West Estonia (Rõuk 1992: 31). Primitive land-tillers preferred the easily cultivable soils with a thin layer of humus, also the woods were fairly sparse there. The sparseness of woods might have also contributed to the first and very early cultivation of these regions (Aasalo \& Rõuk \& Sander 1982: 19-20). Such limestone regions were densely populated already in the Bronze Age and especially in the early Iron Age. Land tillers of that time often exhausted the soils with the thin layer of humus on limestone, so the originally fertile lands became barren after a short period of intense cultivation (EEA 1982: 197). The cultivation without additional fertilisation proved impossible. During recent years several of the earliest known fields, i.e. tens of hectares of field systems with balks and heaps of field stones mostly from the Early Iron Age, were found in the regions with such soils (Lang 1990; 1994; 1995; 1996). The largest and most cultivable massifs of such light soils rich in humus are found on Saaremaa, around Tallinn and Rapla, Hageri and Kohila, also in North-East Estonia (EEA 1982: 170) - i.e. in the areas richest in cup-marked stones.

In Finland, the distribution of cup-marked stones correspond to the distribution of fertile loamy soils (Taavitsainen 1990: 67-68). In Häme, for example, such loamy soils were the first to be cleared for cultivation with the spread of settlement during the Iron Age and the Middle Ages (Taavitsainen 1990: 67-68; Orrman 1991; Tvauri 1993). An exception here is southern Savo with little fertile loamy soils (Orrman 1991). However, the majority of cup-marked stones in the Kerimäki region in South Savo north-east of Savonlinna is located on more fertile supra-aquatic soils, although only a quarter of the soils of the region is supra-aquatic (Simola \& Grönlund \& Huttunen 1984: 21, Kirkinen 1994: 74). 
At least in northern Estonia cup-marked stones occur more widely than stone burial places that have been associated with them. An abundance of cup-marked stones can be found near Kuivajõe-KoluOru-Tuhala in the south-eastern part of Harjumaa county, but no stone burial places. On the premises of today's Rapla county in the southern part of Harjumaa, which is extremely rich in cup-marked stones, one can find only single burial places from the Late Iron Age. This fact bears witness to the close relationship between cupmarked stones and land-cultivation. People may have cultivated the fallow fields further away from villages as well: if cup-marked stones are associated with fields and fallows, they could also be found further away from burial places and settlements.

The cup-marked stones of South Savo are clearly connected with fields in particular, rather than agricultural settlement in general. 86.6\% of cup-marked stones in South Savo are located on the ground sloping towards east, south-east, south, south-west or west (Kirkinen 1994: append. 37). The micro-climate of these latitudes has been greatly influenced by the uneven distribution of sunlight that reaches the ground depending on the exposition and tilt of the slopes. The southern slopes are considerably more exposed to sunlight than the even land or northern slopes, and are therefore much warmer (Jõgi \& Tarand 1995: 195-196).Vegetation period is longer on southern slopes, as snow thaws there much earlier than on the even land or northern slopes. As South Savo with its northernmost and inland geographical position is one of the Iron Age agricultural regions with the most unfavourable climate in Finland, every single day of the vegetation period and every degree of warmth was of great importance there. In the North and West Estonian plains with limestone subsoil this factor was less relevant.

The example of South Savo also suggests that cup-marked stones were located further away from lakes and rivers than any other ancient archaeological monument (Kirkinen 1994: 74). Therefore, the cup-marked stones were necessarily associated with settlements, the location of which was first and foremost conditioned by the easy access to water.

The Kerimäki region in South Savo lacks archaeological monuments suggesting the existence of Iron Age settlements such as settlement sites or burial places, altogether. All palynological factors 
indicate the intense woodland burning in Kerimäki region between the years 600 and 800 , at the same time, the palynological indiccators show hardly any traces of human activity in this region at other pre-Christian periods (Simola \& Grönlund \& Huttunen 1984: 18-19). Scholars have speculated that Kerimäki region was once a distant assarting tract of the people of Häme (Taavitsainen 1988: 222-224); and Häme is one of the regions richest in cupmarked stones in Finland. Apparently, the cup-marked stones of Kerimäki date back to the very same assarting period in the 7th8 th century.

The cup-marked stones of Kerimäki are located in the area of fallow fields with no permanent settlement. The reason why people did not settle there during the Iron Age is that at these times Finnish land-tillers preferred to cultivate fertile loamy soils (Taavitsainen 1990; Orrman 1991; Tvauri 1993), which are relatively rare in South Savo. Also, the real purpose of Finnish peasants might have not been so much the founding of permanent settlement in distant assarting regions, the distant wastelands were used for hunting fur animals. Eljas Orrman, the Finnish historian, has noted that the harvest from assarted lands further away from settlements was first and foremost meant for providing local food for those hunting at such distant wastelands (Orrmann 1991). Moreover, assarting helped to increase the number of wild animals (Taavitsainen 1994: 199) as well as hunting game in these regions, as big game prefer to feed from the young stands.

The number of discovered ancient fields in Finland is so small that no comparison can be drawn between the distribution of them and cup-marked stones. The only known direct evidence of cultivation in the imminent surrounding of a cup-marked stone was discovered in the Merovingian settlement Malax Kalascharbrännan on the western coast of Finland, where ancient plough traces were found between six cup-marked stones (Liedgren 1991: 126-129).

In Scandinavia, cup-marks were closely related to the sc. SouthScandinavian petroglyphs originating from the Iron Age, mostly. Cup-marks are still considered one of the motifs of rock-carvings in this region. Ulf Bertilsson argues in his doctorate thesis on the basis of the example of Bohuslän county in western Sweden which is extremely rich in petroglyphs that the traditions of making rock- 
carvings and cup-marks are closely interrelated (Bertilsson 1987: 190). In the same work he emphasises that in nature rock-carvings are often situated in the imminent vicinity of cultivable land (Bertilsson 1987:191).

Therefore, the cup-marked stones and rocks are first and foremost associated with assarting. The cup-marked stones of Savo, for instance, are related not so much to long-cultivation but to assart cultivation. Observing the archaeological sites in the vicinity of Tallinn, Valter Lang has noted that the majority of cup-marked stones are located on the boundaries of the ancient settlements, whereas the number of cup-marked stones in the centre of these settlements is relatively small. He has assumed that it refers to the function of cup-marked stones to mark boundaries (Lang 1996: $382,392,399,400,413-414)$. The author of the current article suggests that such particular distribution of cup-marked stones might refer to their relation to assarting. The long-cultivated fields were located mostly closer to villages, whereas the assarting took place for a longer time in peripheries and less used fields (and also in boundary regions).

In conclusion, we might say that the distribution of cup-marked stones in Estonia, Finland and Scandinavian countries is closely connected with land-cultivation. The position of the stones in nature is not so directly connected with settlements and ancient burial places but they can be associated with (assarted) fields. Therefore, the cup-marked stones might very likely be considered indicators of primitive agriculture.

\section{THE TIME OF MAKING CUP-MARKS}

Artefacts found in the cultural layer have been of great help in establishing the age of the majority of archaeological sites. However, no cultural layer can be associated with cup-marked stones and no artefacts have been found near them. The basic starting point in the dating of cup-marked stones have been the area of distribution and their position relative to natural surroundings and other archaeological remnants. 
One of the means for determining the age of the cup-marks has been the position of cup-marked stones from the water level. The ground surface in the northern and western part of Estonia has gradually risen during the whole post-glacial period; the process was fastest after the melting of ice sheet, later it has become inconsistently slower. Thus, the cup-marked stones in the lowest position relative to the water level are most relevant in determining the age of such stones, as no cup-marks could be made before the stones actually subjected to denudation from the water.

Almost all Estonian cup-marked stones are located quite high above water level, in the regions denuded from water already during the Stone Age or regions which have not been under water after the last glacial period. Only single stones are located closer to the water level; hereby I intend to focus on these particular stones.

Two lowest cup-marked stones in northern Estonia are both situated in the administrative area of Tallinn. One of them is on the island of Aegna nearly $15 \mathrm{~km}$ north from the city centre of Tallinn, 7.5 metres above the sea level (Viidas 1992: 22). That stone discovered by Oskar Raudmets is very large and has five distinctive wellpreserved cup-marks (Tallinn 2475). There is no reason to doubt that the stone really is a cup-marked stone and is located in its original place. The fact that it is situated on a small island is quite exceptional, thus the cup-marked stone of Aegna can be compared with the cup-marked stones on the island of Vilsandi. The second cup-marked stone positioned low above the water level is located in the inner yard of Koidula street 21a, Kadriorg quarter in Tallinn, between streets Koidula and Weizenberg (Tallinn 24-k). This position of this stone above water level is approximately the same than that of the Aegna stone. The Kadriorg cup-marked stone is large, nearly 2 metres high, which also suggests that the stone is at its original place. The two cup-marks on top of the stone are relatively deep but weathered to a degree that the author of the current article dares not to consider them man-made with full certainty. There is a third stone in Tallinn (Tallinn 11-k) as well, which was supposedly located quite low from the water level in the past. Today, the cup-marked stone is situated in a home garden at Räägu street where it was most likely brought from around Tehnika street. Even earlier the stone is said to have been located near the sea in Kopli 
quarter in Tallinn (Viidas 1992: 22). The original location of the stone is, however, not known.

On the island of Vilsandi, two cup-marked stones positioned relatively low above the sea level have been discovered; one of them has four and the other one at least six cup-marks (Saare county 53$\mathrm{k}, 54-\mathrm{k})$. The stones are located in the highest part of the island, in the range of 4-7.5 metres above the sea level. Also, the only known cup-marked stone of Muhu Island in the Aljava village is located near the coastline (Lõugas 1995: 77) ${ }^{1}$.

Considering the rate of the rise of ground level in the coastal regions of Estonia we might note that the above mentioned stones have been denuded from water as late as in the Bronze Age or the first half of the Iron Age. It is not possible to determine it more precisely. The rate and changes in the rise of ground level has never been thoroughly researched in Estonia. According to the archaeologist Vello Lõugas, the data concerning the rate of the rise of ground level provided so far is not always reliable for dating archaeological objects. According to this data, the fortified settlements of Asva and Ridala, for example, would still have been under the sea level during the period they were used, i. e. in the Early Iron Age. The same applies to the Kahtla stone burial places in Saaremaa, located nearly 6 metres above the sea level.

In Finland, the rise of the ground level was considerably faster than in the coastal regions of Estonia, also its rate and the changes in coastline have been studied thoroughly. Therefore, it is much easier to establish the age of archaeological monuments in Finland. The majority of South Pohjanmaa cup-marked stones and rocks are located in the regions that are denuded from water around the year $350 \mathrm{AD}$. The main part of cup-marked stones around Turku were denuded from water after the year 450 BC (Tvauri 1995: 59). Hurrying ahead we might say that the tradition of making cupmarks lasted much longer in Finland than in the Scandinavian countries or in Estonia; the cup-marks on the Savo stones, for example, date back to the period between years 600 and 800 .

The results of archaeological excavations do not enable to determine the age of cup-marked stones in Estonia more precisely. Only cup-marks on the stones found in Kuusalu, Harjumaa county and 
from the ruins of a stone in Aindu near Viljandi can be dated with more certainty, originating from the years 1100 and 1200, respectively. Still, these stones might be even considerably older, as neither of them was discovered in their original location.

To establish the age of cup-marked stones we should compare their distribution with that of the other fixed archaeological monuments that could be dated more easily, i.e. we should determine the age of other archaeological monuments that are most closely associated with the cup-marked stones. Such method was used by Vello Lõugas already in his article published in 1972.

We can not date the Estonian cup-marked stones to the Stone Age according to their distribution, as the distribution of other archaeological monuments from that period is totally different from that of cup-marked stones. Also, the distribution of the archaeological monuments and occasional findings from the Late Bronze Age (1500-1000 BC) does not enable us determine the time of making cup-marks in this certain period.

Very often, however, cup-marked stones have been found near the stone burial places from the Early Bronze Age (1000-500 BC) and the Pre-Roman Iron Age (500 BC-50 AD) and the earlier tarandburial places from the Pre-Roman Iron Age (Lang 1996) (Figure 18). Several exceptions could be found as well: near the stone burial

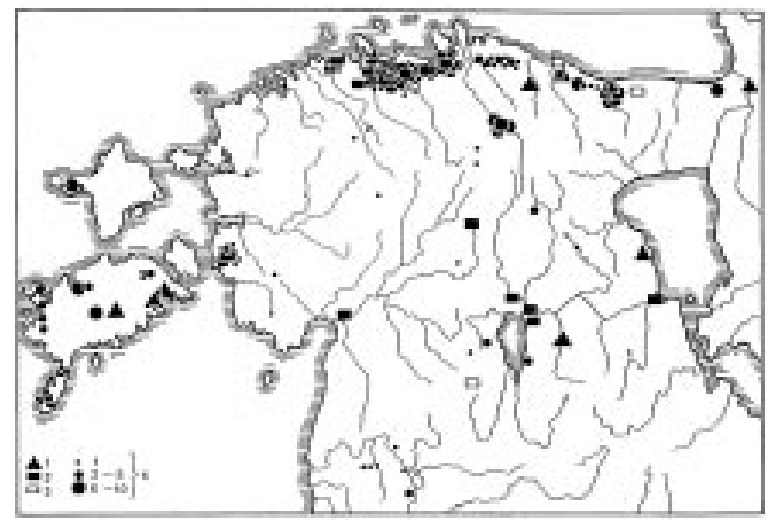

Figure 18. The distribution of Bronze Age and Early Iron Age archaeological monuments in Estonia (after Vello Lõugas, complemented by the author). 1 -fortified settlements; 2 - open settlements; 3 - supposed open settlements; 4 -stone setting. 
places in Kõpu peninsula in Hiiumaa, the surroundings of Võhma Village in Mustjala parish in Saaremaa and the surroundings of Lake Kahala in Kuusalu parish in Harjumaa county no cup-marks stones have been found so far. The same applies to the northern part of Vaivara parish. ${ }^{2}$ Still, there is no reason to assume that the distribution of cup-marked stones should completely coincide with that of the settlements and burial places from the same period. The cup-marks were made into stones first and foremost in the closest vicinity of fields, but the asserts could be located quite far from settlements and burial places. We should also consider the assumption that the beliefs related to making cup-marks into stones were not evenly spread, or they were spread in different regions at different times, or were unevenly intense in different regions.

In northern and western Estonia the cup-marked stones are often found near tarand-burial places from the Roman Iron Age 50-450 $\mathrm{AD})$, whereas in South Estonia and North Latvia no cup-marked stones are generally found near tarand-burial places.

Cup-marked stones can be found near the archaeological monuments from the later periods of Iron Age also in the northern and western parts of Estonia only. During the Great Migration (450$700)$, the Pre-Viking period ( 700 - 850) and the Viking period (850$1050 \mathrm{AD}$ ) new settlements with no found cup-marked stones were founded in these regions as well. Several of them are located in, say, the southern part of Harjumaa county, the eastern part of Läänemaa county, and West-Saaremaa. No cup-marked stones have been discovered near the tumuli originating from the second half of the first millennium in South-East and East-Estonia. The distribution of archaeological monuments from the Late Iron Age (1050 - mid-13th century) differs even more from that of the cupmarked stones.

The relation with other archaeological monuments might suggest that the cup-marked stones belong to the period that lasted from the Early Bronze Age until the end of the Pre-Roman Iron Age. Thus, the seven-times increase in the number of cup-marked stones since 1972 (from 250 to 1750) has not changed their dating to the Bronze Age and the Early Iron Age, originally established already by Vello Lõugas (Lõugas 1972). 
There is no reason to doubt that the tradition of making cup-marks was spread to the Estonian territory from the east, the Scandinavian countries. The number of cup-marked stones and rocks in Scandinavia is many times larger than the same number in Estonia; the southern part of the Scandinavian peninsula has surpassed the eastern coast of the Baltic both in its population and its economic potential ever since the Late Stone Age. Even during the Bronze Age and the Iron Age the southern part of Scandinavia was a cultural centre, whereas Estonia has always functioned as a periphery of the Scandinavian countries.

Although the tradition of making cup-marks was known in Denmark and Sweden already in the Early Stone Age (e.g. Glob 1969: 119, 128; Malmer 1989: 11-12), both cup-marked stones as well as rock-carvings are dated mainly to the Bronze Age in the Scandinavian countries (e.g. Glob 1969: 128; Østmo 1990: 118). It is generally known that the cup-marks in southern Scandinavia are clearly related to other rock-carvings, most of them dating back to the Bronze Age (the petroglyphs represent boats, sun discs, men, people ploughing with oxen and ploughs, etc.). At the same time it is argued that the making of cup-marks in Scandinavia has continued well into the Pre-Roman Age (e.g. Glob 1969: 125; Lindälv 1975; Burenhult 1979: 26; Malmer 1989: 11-12; Østmo 1990: 118).

As Sweden could be reached mostly by sea, we have reason to believe that the oldest cup-marked stones of Estonia are located in coastal regions. Presumably, the tradition of making cup-marks reached first the densely populated regions in the north-western part of Estonia.

At what time did the tradition of making cup-marks reached Estonia? The Bronze Age origin of the Estonian cup-marks is somewhat questionable, as the South-Scandinavian rock-carvings with local agricultural motifs are not known east from the Baltic Sea; the well-known rock-carvings of Lake Onega represent different motifs and are mostly hunting-related. Scientists have so far failed to date the cup-marks of certain Estonian cup-marked stones in the Early Bronze Age. However, it is plausible that the cup-marks of some stones do belong to the end of the Bronze Age. According to the data provided by the archaeologist Tanel Moora several cupmarked stones south-east and south from Tallinn are located in 
low-lying swamp soils, such as around the Rae swamp. It is not plausible that the cup-marks were made to stones in swamps, thus, the cup-marks of these stones might belong to the Bronze Age, the final period of subboreal climate when the foggy cavities of this region were considerably drier than today (Moora 1974: 137).

The origin and spreading of the custom of making cup-marks seems to fall in the general context of the Scandinavian cultural influence in the Bronze and Early Iron Age. The Estonian Bronze Age material culture (the bronze artefacts in particular) too obviously copies the Scandinavian examples (Jaanusson 1993: 11). Sweden and Estonia had close contacts even during the Pre-Roman Iron Age, and apparently it is from the Swedish that the ancestors of the Estonians learned how to work iron. The gradual spread of the custom of cremating the dead might also be related to the Scandinavian influence (Ligi 1993: 14). Several linguists argue that the influence of the Germanic languages brought along the separation of the Balto-Finnic languages from the Sami ones during the Bronze Age. The influence that the Germanic languages exerted over the Balto-Finnic languages in those times has penetrated into the very structure of the latter in a way which implies that a great number of the population in the contact region was bilingual (Strade 1992: 572-573). Particularly significant is the agricultural vocabulary among the old Germanic loans (EEA 1982: 162).

As the cup-marks are the only motif of the Scandinavian rock-carvings that are sometimes dated in the Iron Age, we might assume that the custom of making cup-marks spread to the eastern coast of the Baltic at the time when the rock-carvings were no longer made but the tradition of making cup-marks was still alive. Thus we have reason to believe that the custom of making cup-marks reached Estonia during the Early Bronze Age or the Pre-Roman Iron Age together with the agricultural methods, represented here by the sc. Celtic fields (Lang 1994, 1995, 1996). Since about the Early Bronze Age the Estonian pollination charts suggest the employing of land which refers to the growth in land usage (Pirrus \& Rõuk 1988: 51; Moe \& Kihno \& Pirrus 1992: 91; Saarse \& Königsson 1992: 122). Considering also the dating of other Scandinavian cultural phenomena (the sc. Celtic fields, stone burial places), we might establish the time of making cup-marks to the Pre-Roman Iron Age. 
During the Roman Iron Age (1st-5th century AD) the contacts between Estonia and Scandinavia were heavily reduced, which is reflected in the increasing differences in the burial customs and material culture. During this period the contacts between the BaltoFinnic and the Baltic tribes came to prevail. New types of artefacts came to Estonia from the Baltic tribal territories (EEA 1982: 241242). This fact also rules out the assumption that the practice of cup-mark making would have reached Estonia from Scandinavia only as late as in the Roman Iron Age. Besides, as mentioned above, the distribution of the tarand-burial places of the Late Roman Iron Age and that of the cup-marked stones do not coincide.

Towards the end of the Late Roman Iron Age at the latest, the custom of making cup-marks had apparently faded. This argument is also supported by the fact that the number of cup-marked stones in the southern part of Estonia and the northern part of Lithuania is very small indeed. If the differences between the West- and NorthEstonia on the one hand, and the South-Estonia and North-Latvia on the other (EEA 1982: 201) were during the Bronze and PreRoman Iron Ages quite significant, then towards the end of the Roman Iron Age (the end of the 2nd - the beginning of the 3rd century) a noticeable cultural consolidation took place in the whole territory of Estonia and the North-Latvian regions, which was reflected in the general spread of tarand-burial places and similar ornaments (Ligi 1995: 224-225). As the expansion of tarand-burial places did not bring along the spreading of cup-marked stones, we have reason to believe that the tradition of making cup-marks was fading or had faded by that time.

To sum up the chapter we might say that the custom of making cup-marks spread from Scandinavia to Estonia at the end of the Early Bronze Age (1000-500 BC) or at the beginning of the PreRoman Iron Age (500 BC - 50 AD). Most of the Estonian cup-marks originate from the Pre-Roman Iron Age. By the end of the Early Roman Iron Age (50-200 AD) at the latest, the custom of making cup-marks had fallen into oblivion, ending in Estonia at the same time as in Sweden, or a little later. In peripheries, however, the custom lasted little longer. In South-Pohjanmaa on the coast of Finland, for example, The cup-marks were made even after the year 350. In South Savo in the mid-Finland the tradition of cup- 
marks continued well into the 7th-8th century (Simola \& Grönlund \& Huttunen 1984: 18-19; Tvauri 1995: 70).

The dating of the Finnish cup-marked stones into a considerably earlier period than that of the Estonian and Scandinavian stones might seem contradictory if we regard the making of cup-marks only as a custom related to some sort of belief. But, assuming that the making of cup-marks was associated to some more material idea, such as assart cultivation, the contradiction is no longer there. The assart cultivation in Finland as the main source of living continued through the whole pre-Christian period, in the central and eastern parts of Finland even well into the 19th century. On the limestone regions in North-Estonia where the majority of Estonian cup-marked stones and the oldest known fields are situated, the assart cultivation was no longer possible. In this area, the assarting lost its original significance and was substituted with permanent cultivation already in the beginning of the Iron Age (Lang 1996).

\section{THE ORIGINAL PURPOSE OF CUP-MARKS}

A number of scientists and amateur researchers have tried to explain the original purpose of cup-marks, but have not yet reached a certain conclusion. The Swedish archaeologist Göran Burenhult has made a witty remark that there are nearly as many attempts to interpret the cup-marks as there are cup-marks themselves (Burenhult 1979: 27). Although a lot has been written about the cup-marks, the research on them is still scarce. The authors focusing on the cup-marked stones of northern Europe often refer to and quote each other.

The original purpose and the beliefs connected to the cup-marks will probably never be known. However, on the basis of the research conducted insofar it is possible to outline the tradition of making cup-marks and shed light on some of its characteristic features.

As mentioned above, cup-marks have been thought, especially in the earlier interpretation to be offering hollows which were carved in stones for placing offerings there (e.g. Tallgren 1917: 96; Viidalepp 1940: 22; Lehtosalo-Hilander 1988: 137; Hirviluoto 1991: 158). Still, we found out in the chapter concerning the position of the cup- 
marks that this assumption is not justified; some of the cup-marks are situated in the vertical or strongly leaning sides of the stones, where it is impossible to place any offerings. Even in connection with the later custom of offering to the stones, gifts have been placed in the cup-marks only on rare occasions.

It has also been suggested that cup-marks have been used to count years, for example (Eelsalu 1981, 1982, 1985; Eelsalu \& Hamel 1980). The quite random position of the cup-marks contradicts this presumption. If the cup-marks had been used for counting, they would be lined up or at least grouped together. Besides, the number of cup-marks on a stone is generally small ( $72 \%$ of the cup-marked stones of Estonia have 10 cup-marks or less). It is also impossible to prove that the cup-marks had been used to mark certain directions. This idea is contradicted by the great number of one-cupmarked stones and the position of cup-marks on different faces and vertical sides of the stones. The use of cup-marks for astronomical objectives in Estonia and other parts of Northern Europe is almost excluded.

The association of cup-marks with the worship of ancestors (see e.g. Viidalepp 1940: 24; Kivikoski 1966: 81-82; Lõugas 1972: 731; EEA 1982: 185; Lehtosalo-Hilander 1988: 135) is also not very plausible, as the cup-marked stones are sometimes situated very far from settlements and burial places. It is most remarkable in Finland, South Savo where the numerous cup-marked stones there are obviously connected with the Merovingian distant assarts of the people of Häme. The centres of Häme settlement are about 300 $\mathrm{km}$ from the region of cup-marked stones in South Savo. Such lengthy trips into wilderness were apparently undertaken by people in their prime whose mortality rate was several times smaller than among those who stayed home (including children and old people). If the cup-marks were to be associated with the cult of the dead, the fact that so many stones have been found so far from the populated centres would have no explanation. For the same reason the making of cup-marks cannot be connected with the birth of children. Disregarding the fact that the example concerns the Meroving period of mid-Finland and not the Bronze and Pre-Roman Iron Age on the Estonian territory we might still draw some generalisations from that: considering the identical appearance and position of the cup-marks in nature, and also the relative similari- 
ties of the cultural space around the Baltic and Finnic Sea, we can assume that the beliefs related to the origin of cup-marks must have been the same at least in the northern Europe. Such regions where the cup-marked stones cannot be associated with permanent settlements and burial places could be found in Estonia as well, in southern Harjumaa, for example.

Scandinavian rock carvings, including the cup-marks, have been considered boundary marks of hunting grounds or private estates (Kjellén \& Hyenstrand 1977: 27; Malmberg 1983). Torsten Malmberg argues that such function of the cup-marks could be inferred from the Vitlycke petroglyph in Bohuslän, Sweden, featuring two men holding up axes, each of them on the other side of the row of cup-marks (Malmberg 1983: 88). Although the cup-marks are located in the boundary regions between settlements rather than in the centres of settlement (Lang 1996), they mark no "boundaries" in the landscape. Also, there is no evidence that the cup-marks were made in most visible or visited places. The cup-marks identical in the whole distribution area contain no information about their creator, which leads us to believe that the cup-marks were not means for human communication.

The cup-marks have also been associated with the cult of fire or fire rubbing (Müller 1917). This assumption, however, does not clarify why the stones should be near the fields. Besides, as I mentioned before, it is improbable that the cup-marks were rubbed into the stones. It is of course not excluded that the roots of the cupmark making tradition reach back to the hollows caused by firerubbing, still, at least in northern Europe there is no reason to associate the cup-marks on stones and rocks with making fires.

Arvi Lauringson, a researcher of local history has drawn attention to the supposed location of cup-marked stones near the deposits of bog ore (Lauringson 1979: 25). In reality, there is no relation between the distribution of cup-marked stones and bog ore. Not a single cup-marked stone has been found near one of the largest ancient iron work centre in Tuiu, Saaremaa. Even in Sweden, one of Europe's richest countries in iron ore, the ancient iron founding areas are located far from cup-marked stones (Hyenstrand 1984: map 31). 
Cup-marks have also been associated with magic fertility rituals (e.g. EEA 1982: 181), so far, however, no evidence supports this argument. In the current stage of research, this assumption seems most plausible. The making of cup-marks in stones and rocks might have served as a magic fertility ritual related to agriculture. As the effect of the magic was generally directed to future, we might assume that making a cup-mark was connected to sowing. Only one cup-mark was made at a time. We have no reason to believe that once the cup-mark had been made, it had any magic or ritual relevance later. For people at this period the cup-marked stones were probably not sacred.

We might conclude from relating the cup-marks to fertility magic that the cultivation of land was more intense and/or the period of making cup-marks was longer at places where the stones had more cup-marks. The distribution map of the stones with more than one hundred cup-marks (Figure 6) reveals that such stones were almost exclusively found in the coastal region of North-Estonia, the earliest agricultural regions of Estonia, where cultivation was the primary source of living already in the Bronze Age.

As the making of cup-marks extends over a relatively long period of time and an extremely wide area, the must have served a general and easily comprehensible purpose.

The cup-marks have been interpreted also as solistic symbols (e.g. Fett \& Fett 1941: 124; Marstrander 1963: 304). However, the Scandinavian rock-carvings suggest that sun was depicted in yet another way: namely, in the shape of a disc with either rays or hands attached to it (Figure 19), similar to the Egyptian sun images from the same period. In the petroglyphs, the sun is also depicted
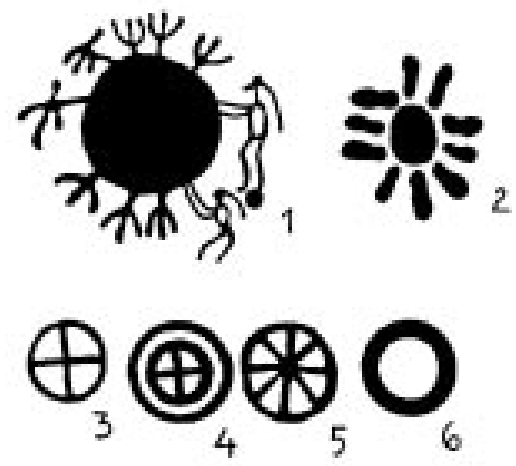

Figure 19. Supposed images of the sun on Scandinavian rock carvings.

1 -Aspeberget, Bohuslän, Sweden; 2 - Boglösaby, Uppland, Sweden; 3-6-different supposed symbols of the sun. 


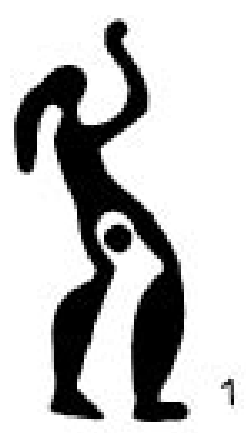

1

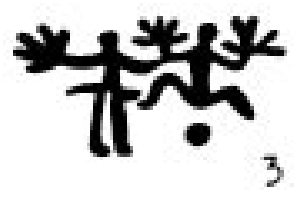

Figure 20. The cup-mark as signifying the female genitals on scandinavian rock carvings.

1 - Åby Backagård, Bohuslän, Sweden;

2-Fossum, Bohuslän;

3 - Rished, Bohuslän;

4 - Isnestoften, Finnmark, Northern Norway.

by the circles and circular crosses. The author of the current article tends to believe that the relation between cup-marks and fertility rites is suggested by a more direct and generally comprehensible set of symbols.

The cup-marks in the Scandinavian petroglyphs sometimes mark female genitals (Figure 20). Next to the nearly ten thousand male figures generally attributed with phalli, the rock-carvings feature a couple of dozens female figures, whose gender is most commonly signified by the cup-mark between the legs. Similar emphasised gender features have been found in the rock-carvings of Val Camonica in the Italian Alps (Burenhult 1979: 27).

The same symbolic meaning might also be conveyed by the oval and pointed-oval forms found in the rock carvings and cup-marked stones in Scandinavia (e.g. Fett \& Fett 1941: table 72; Glob 1969: fig. 13; Marstrander 1963: fig. 71:13). Although the oral tradition of Estonian and other Nordic countries contain no information of the relation between cup-marked stones and fertility magic, the late popular tradition from different part of the world contains a number of references to it. In Palestinian popular tradition, for example, similar cup-marks carved in the rock have been clearly associated with the cult of Earth Mother (Almgren 1926-1927: 221222). The cup-marked rocks in India have also been connected to the fertility magic in popular tradition: even in the 19th century 
India similar cup-marks have been made on the rocks at the side of the road of the bridal procession (Rivett-Carnac 1877: 15). Also, it cannot be excluded that the cup-marks made on the Nordic and Estonian stones are associated with the ritual fecundating of earth.

\section{Comments}

${ }^{1}$ In Kurevere parish village in Saaremaa, seven cup-marked stones were found nearly on the sea coast, on a low coastal pasture less than 8.5 metres above the sea level. As mentioned before, these stones are probably brought to their today's location. The stones are positioned side by side, forming a row, and are not deep-sitting as most of the Estonian boulders but lay on the ground. On the side of one of the cup-marked stones of Kurevere, Vello Lõugas has discovered a rim without mossy covering $15-20 \mathrm{~cm}$ from the ground; the part lower from the rim has most probably been once under the ground. Higher from the rim the stone is covered with rattling lichen (Lõugas 1995, 74). We might assume that the stones were brought to their today's location by the owner of Pidula estate, Baron Bernhard von Toll or his grandfather Eduard von Toll. A keen collector of archaeological artefacts Bernhard von Toll reported the existence of these stones to the archaeologists as well (Lõugas \& Selirand 1989, 216-217).

${ }^{2}$ For a long time no cup-marked stones had been found in the Sõrve peninsula famous for its numerous stone burial places. In August 1995, however, Vello Lõugas managed to discover two cup-marked stones in Easte village, Anseküla parish.

\section{References}

\section{Manuscripts}

Aasalo, L. \& Rõuk, A.-M. \& Sander, A. 1982. Väo loopealse ja Maasepa ümbruse (Lasnamäe IV ja V mikrorajooni) maastike uurimised. Tallinn. Manuscript in the library of the Institute of History.

Amandus, A. 1939. Andmeid esiajaloolisest ajast Viljandi kihelkonnas. (Data gathered in 1935, presented in 1939.) Manuscript in the library of the Institute of History. 
Asplund, H. 1990. Turun seudun uhrikivet. Manuscript in the archive of Museovirasto (Helsingi).

Jürgens,A. 1921. Palamuse kihelkond. Manuscript in the archive of the archaeology sector of the Institute of History.

Kirkinen, T. 1994. Etelä-Savon ja-Karjalan nuoremman rautakauden asutuksen suhde luonnonympäristöön ja taloudelliseen ympäristöön. Arkeologian pro gradututkielma. Manuscript in the Chair of Archaeology of Helsinki University.

Parmas, O. 1925. Kuusalu kihelkond. Manuscript in the archive of the archaeology sector of the Institute of History.

Saukkonen, J. 1984. Hämeenlinnan inventointikertomus. Manuscript in the archive of Museovirasto (Helsiki).

Saukkonen, J. 1985. Hattulan inventointikertomus. Manuscript in the archive of Museovirasto (Helsinki).

Tiismaa,A. 1922. Pöide kihelkond. Manuscript in the archive of the archaeology sector of the Institute of History.

Tvauri, A. 1995. Viron ja Suomen kuppikivet. Pro gradu-työ. Manuscript in the Chair of Archaeology of Helsinki University.

Valk, H. 1993. Aruanne jätkukaevamistest Aindu muinasasula kohal 22. juunil-09. juulil 1993. a. Tartu. Manuscript in the chair of archaeology in Tartu University.

Vilbaste, G. 1956a. Kiri Teaduste Akadeemia ajaloo osakonnale. Manuscript in the archive of the archaeology sector of the Institute of History (Kuusalu khk).

Vilbaste, G. 1956b. Kohanimed Loksa rajooni lääneosas (endises Kuusalu kihelkonnas). Peatükk asustusajaloost. Manuscript in the Estonian Folklore Archives (Tartu).

Scientific passports of cup-marked stones as registered in the National Heritage Inspectorate (systematised by county and identification number).

\section{Publications}

Almgren, O. 1926-1927. Hällristningar och kultbruk. Stockholm. Aspelin, J. R. 1895. Uhrikiviä. Suomen Museo II, pp. 1-3.

Bertilsson, U. 1987. The Rock Carvings of Northern Bohuslän. Spatial Structures and Social Symbols. Stockholm Studies in Archaeology, 7.

Bertilsson, U. 1989. Rock-Carvings, Ideology and Society in the Bronze Age of western Sweden. Bronze Age Studies: Transactions of British-Scandinavian Colloquium in Stockholm, May 10-11, 
1985. Stockholm. Statens historiska museum. Studies, 6, pp. 101109.

Burenhult, G. 1979. Hällristningar. Hällbilder från sten- och bronsålder $i$ Norden. Malmö.

Burenhult, G. 1980. Götalands hällristningar. Del I Theses and Papers in North-European Archaeology, 10.

Coles, J. 1995. Hällristningar $i$ Uppland. En vägledning. Uppsala.

EEA 1982= Jaanits, L. \& Laul, S. \& Lõugas, V. \& Tõnisson, E. Eesti esiajalugu. Tallinn.

Eelsalu, H. 1981. Kolletamispäevale mõeldes.Keel ja Kirjandus, 9, pp. 548-550.

Eelsalu, H. 1982. ... ja tehislohkudega kivide otstarbest üldse. Eesti Loodus, 5, p. 319.

Eelsalu, H. 1985. Ajastult ajastule. Tallinn.

Eelsalu, H. \& Hamel, J. 1980. Väikeste tehislohkudega kivid ja paleoastronoomia. Eesti Loodus, 6, pp. 379-381.

Eisen, M. J. 1918/19. Pühad kivid. Eesti Kirjandus, pp. 155166.

Elstrok, H. \& Tamla, T. 1987. Mida noiduse kivid nie onvad? Horisont, 8, p. 24.

Fett, E. \& Fett, P. 1941.Sydvestnorske helleristninger. Rogaland og Lista. Stavanger.

Glob, P. V. 1969. Helleristninger i Danmark. Jysk Arkæologisk Selskabs Skrifter, VII.

Hasselroth, Pehr, 1984. Hällbilder. Hotade fornminnen. Stockholm

Hasselrot, P. \& Ohlmarks, Å. 1966. Hällristningar. Stockholm.

Hermann, U. 1973. Kuusalu Lauritsakivi ja silmaallikas. Eesti Loodus, 6, p. 347.

Hirviluoto, A.-L. 1991. Salon esihistoria. Jyväskylä.

Holzmayer, J. B. 1873. Osiliana. Verh. GEG, VII:2, Dorpat, pp. $1-121$.

Hyenstrand, A. 1984. Fasta fornlämningar och arkeologiska regioner. Riksantivarieämbetet och Statens Historiska Museer. Rapport RÄ̈ 1984:7. Stockholm.

Jaanusson, H. 1993. Eesti ja Rootsi sidemetest muinasajal. Kivija pronksiaeg. Eesti ja Rootsi. Tallinn, pp. 9-13. 
Jung, J. 1898. Muinasaja teadus Eestlaste maalt, II. Kohalised muinasaja kirjeldused Liivimaalt, Pernu ja Viljandi maakonnast. Jurjev.

Jung, J. 1899. Muinasaja teadus Eestlaste maalt, I. Üleüldine muinasaja kirjeldus. Jurjev.

Jung, J. 1910. Muinasaja teadus Eestlaste maalt, III. Kohalised muinasaja kirjeldused Tallinnamaalt. Tartu.

Jõgi, J. \& Tarand,A. 1995. Nüüdiskliima. Eesti Loodus. Tallinn, pp. 183-216.

Kaliff, A. 1995. Kulthus och spår av gravritualer från bronsålder. Tor. Tidskrift för arkeologi, 27:1. Uppsala, pp. 233-247.

Kivikoski, E. 1966. Suomen kiinteät muinaisjäännökset. SKS Tietolipas, 43. Helsinki.

Kjellén, E. \& Hyenstrand, A. 1976. Upplands hällristningar.

Kjellén, E. \& Hyenstrand, A. 1977. Hällristningar och bronsålderssamhälle i sydvästra Uppland. Upplands fornminnesförenings tidskrift, 49. Uppsala.

Laid, E. 1938. Zwei glaubenskundliche Bodenaltertümer. Sitzungsberichte der Gelehrten Estnischen Gesellschaft, 1936, pp. 77-94.

Lang, V. 1990. Über die Formierung der frühen Tarandgräber im östlichen Ostseegebiet. Congressus Septimus Internationalis Fenno-ugristarum, Debrecen, 27.VIII-2.IX.1990. Sessiones sectionum dissertationes historica, archaeologica et antropologica. Debrecen, pp. 308-313.

Lang, V. 1994. Fossil Fields at Saha-Loo. Eesti Teaduste Akadeemia toimetised, 1, pp. 22-26.

Lang, V. 1995. Varane maaviljelus ja maaviljelusühiskond Eestis: ääremärkusi mõningate arengutendentside kohta. Muinasaja Teadus, 3. Eesti arheoloogia historiograafialisi, teoreetilisi ja kultuuriajaloolisi aspekte. Tallinn, pp. 116-181.

Lang, V. 1996. Muistne Rävala. Muistised, kronoloogia ja maaviljelusliku asustuse kujunemine Loode-Eestis, eriti Pirita jõe alamjooksu piirkonnas. Muinasja Teadus, 4. Tallinn.

Lauringson, A. 1979. Kas muistse meistri proovitöö? Horisont, 10, pp. 24-25.

Lavi, A. \& Mandel, M. 1985. Toolse muinasteadlase pilguga. Horisont, 9, pp. 34-37. 
Lehtosalo-Hilander, P.-L. 1988. Esihistorian vuosituhannet Savon alueella.Savon historia, I. Toinen kokonaan uudistettu laitos. Kuopio.

Liedgren, L. 1991. Merovingertida bebyggelselämningar på Kalascharbrännan i Malax. Järnåldersbygd i Österbotten. En ekologisk-arkeologisk studie av bosättningskontinuitet och resursutnyttjande. Aeta Antiqua Ostrobotniensia. Studier $i$ Österbottens förhistoria, 2. Vasa, pp. 103-146.

Ligi, P. 1993. Eesti ja Rootsi sidemetest muinasajal. Rauaaeg. Eesti ja Rootsi. Tallinn, pp. 14-20.

Ligi, P. 1995. Ühiskondlikest oludest Eesti alal hilispronksi- ja rauaajal. Eesti arheoloogia historiograafialisi, teoreetilisi ja kultuuriajaloolisi aspekte. Muinasaja Teadus, 3. Tallinn, pp. 182270.

Lindälv, E. 1975. "Kungsbord” och andra skålgropsstenar i norra Halland. Vår bygd, 58, pp. 5-20.

Lõugas, V. 1972. Väikeste lohkudega kultusekivid. Eesti Loodus, 12 , pp. 729-732.

Lõugas, V. 1995. Saaremaa väikeselohulised kultusekivid. Saaremaa muuseum. Kaheaastaraamat 1993-1994. Kuressaare, pp. $62-88$.

Lõugas, V. \& Selirand, J. 1989. Arheoloogiga Eestimaa teedel. Teine, parandatud ja täiendatud trükk. Tallinn.

Malmberg, T. 1983. Räkna med revir. Stockholm.

Malmer, M. P. 1989. Bergkonstens mening och innehåll. Hällristningar och hällmålningar i Sverige, pp. 9-28.

Mandel, M. 1983. Kas kolm tuhat aastat asustust? Horisont, 3 , pp. 26-27.

Marstrander, S. 1963. Østfolds jordbruksristninger. Oslo.

Moe, D. \& Kihno, K. \& Pirrus, R. 1992. Anthropogenic Disturbance of Vegetation in Estonia Through the Holocene Based on Some Selected Pollen Diagrams. A Preliminary Survey. Estonia: Nature, Man and Cultural Heritage. Proceedings of a Round Table held at Tallinn, April 1991 at the Estonian Academy of Sciences. PACT, 37, pp. 79-95.

Moora, T. 1974. Maastiku ja muinasaja maaviljelusliku asustuse seostest. Harju rajoonis. Kodu-uurijate seminar-kokkutulek 11.-14. juulini 1974. Tallinn, pp. 130-141. 
Moora, T. 1977. Raskopki kamennogo mogil'nika u ber. Uuri v severnoi Estonii. Eesti Teaduste Akadeemia toimetised, l, pp. 5255 .

Müller, S. 1917. Skaalformede fordybningar, hellige tegn for ilden. Årbøger for nordisk oldkyndighed og Historie. København.

Orrman, E. 1991. Geographical Factors in the Spread of Permanent Settlement in Parts of Finland and Sweden from the End of the Iron Age to the Beginning of Modern Times. Fennoscandia archaeologica, VIII, pp. 3-21.

Pirrus, R. \& Rõuk, A.-M. 1988. Inimtegevuse kajastumisest Vooremaa soo- ja järvesetetes. Loodusteaduslikke meetodeid Eesti arheoloogias. Tallinn, pp. 39-53.

Ramqvist, P. H. 1989. Ångermanland, Västerbotten och Lappland. Hällristningar och hällmålningar $i$ Sverige, pp. 213223.

Rantanen, O. \& Solantie, R. 1987. Climatic Risks to theYield and Quality of Field Crops in Finland, II. Cultivation Zones and Sub-division. Annales Agriculturae Fenniae, 26, pp. 19-37.

Raudmets, O. 1964. Kivid kõnelevad... Harju Elu, 28. mai.

Raudmets, O. 1965. Haruldasi muinasleide Tallinna lõunapoolsest ümbrusest. Pilt ja Sõna, 2. veebruar.

Raudmets, O. 1967. Ohvrikivid juhivad muinasasulatele. Horisont, 11, lk 59-62.

Raudmets, O. 1974. Mida kultusekivid jutustavad muinasajast. Harju rajoonis. Kodu-uurijate seminar-kokkutulek 11.-14. juulini 1974. Artiklite kogumik. Tallinn, pp. 142-151.

Raudmets, O. 1975. Asustamata, aga ometi tihedasti asustatud. Horisont, 4, pp. 35-37.

Rivett-Carnac, H. 1877. Rough Notes on Some Ancient Skulpturings on Rocks in Kamaon. Journal of the Asiatic Society of Bengal. Part I, vol 46. Calcutta.

Rõuk, A.-M. 1992. Looduslikud olud hilisjääajast tänapäevani. Eesti talurahva ajalugu, I. Tallinn, pp. 16-41.

Saarist, T. \& Tõnisson, E. 1986. Paide rajooni ajaloo- ja kultuurimälestised. Tallinn.

Saarse, L. \& Königsson, L.-K. 1992. Holocene Environmental Changes on the Island of Saaremaa, Estonia. Estonia: Nature, Man and Cultural Heritage.Proceedings of a Round Table held at Tallinn, April 1991 at the Estonian Academy of Sciences. PACT, 37, pp.97131. 
Selinge, K.-G. 1989. Västergötland. Hällristningar och hällmålningar $i$ Sverige, pp. 131-146.

Simola, H. \& Grönlund, E. \& Huttunen, P. 1984. Ovatko Kerimäen uhrikivet rautakautisia? Piirtoja itäsuomalaiseen menneisyyteen. Veijo Saloheimolle omistettu juhlakirja, pp. 12-27.

Simonsen, P. 1971. Sydskandinavisk i Nord-Skandinavien. KUML. Årbog for Jysk arkæologisk Selskab 1970. København, pp. 233-242.

Solantie, R. 1988. Climatic Conditions for the Rye with Reference to the History of Settlement in Finland. Fennoscandia Archaeologica, V, pp. 3-20.

Strade, N. 1992. Suomalainen etnogeneesi kielihistorian valossa. Suomen varhaishistoria. Tornion kongressi 14-15.6.1991. Esitelmät. Referaatit. Studia Historica Septentrionalia, 21. Rovaniemi, pp. $568-576$.

Taavitsainen, J.-P. 1988. Wide-Range Hunting and Swidden Cultivation as Prerequisites of Iron Age Colonization in Finland. Suomen Antropologi, 4, 1987, pp. 213-233.

Taavitsainen, J.-P. 1990. Ancient Hillforts of Finland. Problem of Analysis. Chronology and Interpretation with Special Reference to the Hillfort of Kuhmoinen. SMYA, 94. Helsinki.

Taavitsainen, J.-P. 1994. Kaskeaminen ja metsästys erämailla. Metsää ja metsänviljaa. Kalevalaseuran vuosikirja, 73. Helsinki.

Tallgren, A. M. 1917. Suomen uhrikivet. Kotiseutu, 10, pp. 95102.

Tamla, Ü. 1994. Field-Works at Jalase ArchaeologicalEthnographic Reserve in 1990-1992. Eesti Teaduste Akadeemia toimetised, 1, pp. 42-45.

Tvauri, A. 1993. On the Locations of Fields and Villages in the Parish of Tuulos, Southern Finland. Fennoscandia Archaeologica, X, pp. 59-63.

Valk, H. 1994a. Rescue Excavations on the Late Iron Age Settlement of Aindu. Eesti Teaduste Akadeemia toimetised, l, pp. 34-41.

Valk, H. 1994b. The End of Excavations on the Late Iron-Age Settlement of Aindu. Eesti Teaduste Akadeemia toimetised, 4, pp. 386-389.

Vassar, A. 1938. Drei Steinkistengräber aus Nordestland. Sitzungsberichte der Gelehrten Estnischen Gesellschaft, 1937, 1. Tartu, pp. 304-364. 
Veiksar, A. 1982. Viljandi rajooni ajaloo-ja kultuurimälestised. Tallinn.

Viidalepp, R. 1939. Iseloomustavat Eesti ohvrikividest. Eesti Kirjandus, pp. 456-468, 490-505, 539-551.

Viidalepp, Richard, 1940. Iseloomustavat Eesti ohvrikividest. Tartu

Viidas, A. 1992. Viimsi ajalugu. Esi-ja keskaeg. Tallinn.

Østmo, E. 1990. Helleristninger av sørskandinaviske former på det indre Østlandet. Fylkene, Buskerud, Akershus, Oslo, Oppland og Hedmark. Universitetets Oldsaksamlings Skrifter. Ny rekke, 12. Oslo. 